\title{
Anaerobic Co-digestion of Wastewater Treatment Pond Algae with Wastewater Sludge
}

\author{
A Thesis \\ presented to \\ the Faculty of California Polytechnic State University, \\ San Luis Obispo
}

\author{
In Partial Fulfillment \\ of the Requirements for the Degree \\ Master of Science in Civil and Environmental Engineering \\ by \\ Daniel E. Heimel
}

December 2010 


\section{Authorization of Master's Thesis}

I hereby grant permission for the reproduction of this thesis in its entirety or any of its parts, without further authorization, provided acknowledgment is made to the authors and advisers.

Daniel Eric Heimel

Date 


\section{Committee Membership}

TITLE:

AUTHOR:

DATE SUBMITTED:

COMMITTEE CHAIR:

COMMITTEE MEMBER:

COMMITTEE MEMBER:
Anaerobic Co-digestion of Wastewater Treatment Pond Algae with Wastewater Sludge

Daniel Eric Heimel

December 2010

Dr. Yarrow Nelson

Dr. Raul Cano 


\section{Abstract \\ Anaerobic Co-digestion of Wastewater Treatment Pond Algae \\ with Wastewater Sludge}

\section{Daniel Eric Heimel}

Microalgae harvested from wastewater treatment ponds can be anaerobically digested to produce biogas, a renewable fuel resource. However, past experiments have shown some limitations of algae digestion. Algal cell walls are thought to be resistant to digestion, and the high protein content of algae can lead to ammonia toxicity in digesters. Co-digestion of algae with substrates containing higher $\mathrm{C}: \mathrm{N}$ ratios (e.g., waste paper) can be used to maintain noninhibitory ammonia concentrations and increase methane production. However, high carbon waste co-substrates have become costly or are not readily available in many communities. Although domestic wastewater sludge has only a marginally higher $\mathrm{C}: \mathrm{N}$ ratio than algae biomass, sludge is a practical co-substrate for treatment pond facilities using primary sedimentation. The present laboratory research evaluated the use of wastewater sludge as a co-substrate with treatment pond algae that were harvested by coagulation and dissolved air flotation. The research was meant to assist in the planning for full-scale algae digestion at a large pond facility in California. The independent variables evaluated were algae/sludge ratio in the digester feed $(100 \%$ to $0 \%)$, organic loading rate (OLR; 2 or $4 \mathrm{~g}$ volatile solids/L-d), and hydraulic residence time (HRT; 20 or $40 \mathrm{~d}$ ), while the main dependent variables were methane yield, volumetric methane production, and the dewaterability of the digester effluents. Co-digestion of algae with sludge was stable, with healthy $\mathrm{pH}$, at all algae/sludge ratios with OLRs up to $4 \mathrm{~g}$ volatile solids loaded per liter digester per day (g VS/L-d) at a 20-d HRT. For digesters fed algae biomass exclusively, at a $2 \mathrm{~g}$ VS/L-d OLR and a 20-d HRT, the methane yield was $0.26 \mathrm{~L} / \mathrm{g}$ VS-d and methane productivity was $0.52 \mathrm{~g} \mathrm{VS} / \mathrm{L}$ digester-d. A control digester fed sludge exclusively, with 
the same loading rate, produced more methane: the yield was $0.44 \mathrm{~L} / \mathrm{g}$ VS-d and production was $0.87 \mathrm{~L} / \mathrm{L}-\mathrm{d}$. No significant synergistic benefit in algae methane yield was observed due to codigestion with wastewater sludge. Extended HRT did not increase methane yield. A digester operating at a 40-d HRT with an algae/sludge ratio of 80/20 and a loading rate of $1 \mathrm{~g} \mathrm{VS} / \mathrm{L}-\mathrm{d}$ gave a methane yield of $0.27 \mathrm{~L} / \mathrm{g}$ VS-d. A smaller volume digester with the same feed operated at a $20-\mathrm{d}$ HRT and a $2 \mathrm{~g} \mathrm{VS} / \mathrm{L}-\mathrm{d}$ OLR, gave a similar methane yield of $0.28 \mathrm{~L} / \mathrm{g}$ VS-d. The effluent from digesters fed only algae dewatered as effectively or better than digesters fed only wastewater sludge. However, freezing of the algae biomass prior to digestion could have affected the results. An engineering model was developed to estimate heating requirements and net electricity production for full-scale algae digesters. For two example climates (Mediterranean and continental desert), the model predicted that despite the lower methane production of algae digestion, heat recovered from cogeneration and electricity generation would be more than sufficient to fulfill the inputs required for algae digestion. For facultative pond wastewater treatment facilities with existing collection and digestion of primary sludge, addition of the algae produced to the digesters is expected to increase electricity production by $120 \%$. 


\section{Acknowledgments}

To Dr. Tryg Lundquist

Thanks for your support and guidance both in the classroom and laboratory. Your commitment and sense of humor were essential to the completion of this project.

To Dr. Yarrow Nelson and Dr. Raul Cano

Thanks for your insight as Project Advisors in the crafting of this thesis.

To Craig Stubler

Thanks for your contribution to the data analysis for this project.

To Ruth Spierling

Thanks for your dedication, perseverance, and for sharing all those hours in the lab with me.

To Sean Thompson

Thanks for your hard work on this project from its inception.

To my research partners

Thanks for your companionship and assistance.

To the California Energy Commission and the Carbon Capture Corporation Thank you for your financial support of this research.

To the staff at the Sunnyvale Water Pollution Control Plant and the San Luis Obispo

Water Reclamation Facility

Thank you for supplying your knowledge and raw materials for this project. 


\section{Table of Contents}

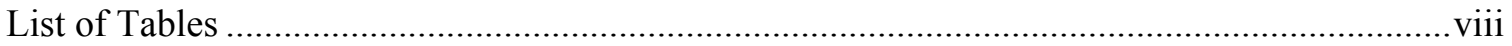

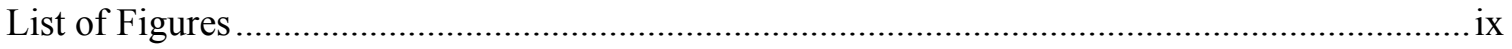

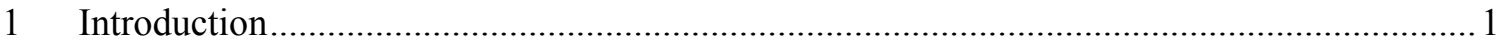

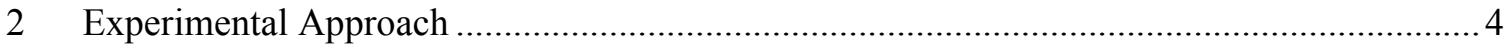

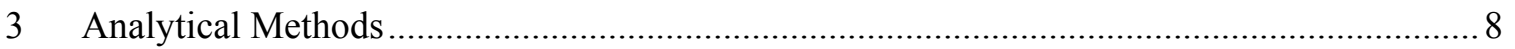

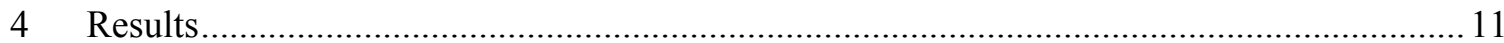

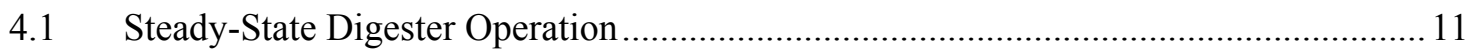

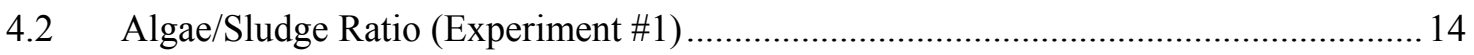

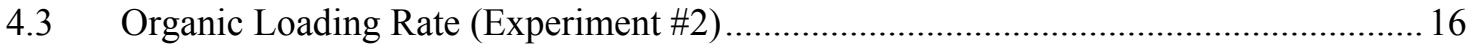

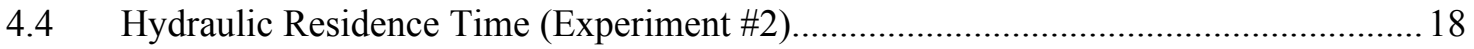

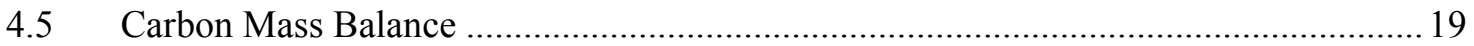

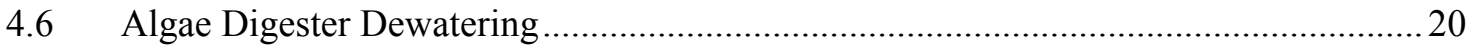

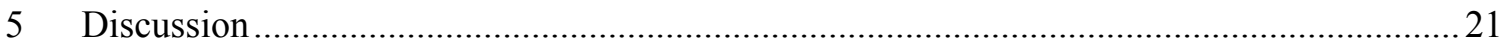

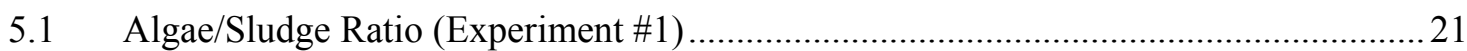

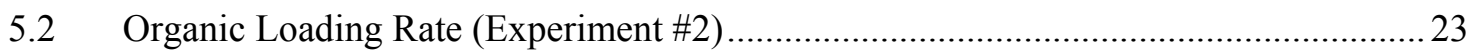

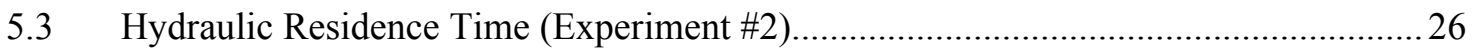

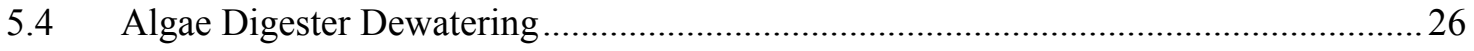

5.5 Algae Digestion Heat Requirements and Energy Balance.........................................2

5.5.1 Scenario 1: Heating Requirement for a Digester Fed 100\% Algae........................ 31

5.5.2 Scenario 2 Existing Facility Conversion from Sludge to Sludge+Algae CoDigestion .................................................................. 32

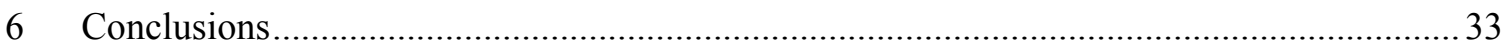

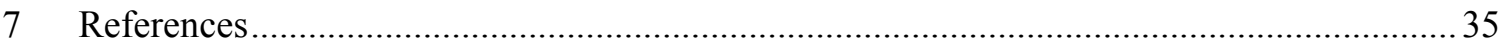




\section{List of Tables}

Table 1: Experimental design for anaerobic co-digestion of algae biomass and wastewater sludge

Table 2. Mean values for each digester during its steady-state operating period.

Table 3. Carbon mass balance results for the steady-state periods

Table 4. Facultative pond wastewater treatment facility assumption

Table 5. Mean monthly air temperatures used in heating analysis

Table 6. Typical digester construction methods and heat transfer coefficients

Table 7. Operating conditions assumed for a digester fed $100 \%$ algae harvested from facultative ponds treating $134,000 \mathrm{~m}^{3} / \mathrm{d}$

Table 8. Operating conditions and electricity production for conversion of a sludge digester to algae co-digestion 


\section{List of Figures}

Figure 1. Schematic of a wastewater treatment pond process with primary clarification and algae separation

Figure 2. Schematic of a wastewater treatment pond process modified to include anaerobic digestion of the algae

Figure 3. The steady-state period selected for Digester \#1-1 (100\% Algae, OLR 2 g VS/L-d, HRT $20 \mathrm{~d}$ ) is representative of the steady-state period for the other digesters.

Figure 4. Volatile solids destruction in Experiment \#1 did not stabilize in digesters with low algae/sludge ratios.

Figure 5. Effect of algae/sludge ratio on methane production rate and yield

Figure 6. Relationship between mean volatile solids destruction and the algae/sludge ratio

Figure 7. Methane yield vs. OLR for $100 \%$ and $80 \%$ algae digesters operated at an HRT of 20 days

Figure 8 . Methane production vs. OLR for $100 \%$ and $80 \%$ algae digesters operated at an HRT of 20 days

Figure 9. Volatile solids destruction vs. OLR for $100 \%$ and $80 \%$ algae digesters operated at an HRT of 20 days

Figure 10. Effect of hydraulic residence time on methane yield, methane production, and volatile solids destruction in $80 \%$ algae digesters operated at an OLR of $2 \mathrm{~g} \mathrm{VS} / \mathrm{L}-\mathrm{d}$

Figure 11. Comparison of dewatering of algae digester and wastewater sludge digester effluent.

Figure 12. Observed effect of algae/sludge ratio on methane yield compared to the anticipated yield

Figure 13. Digester \#2-2 (100\% algae, OLR 4 g VS/L-d, HRT 20 d) exhibiting instability symptoms due to excessive OLR caused by loss of digester volume due to leakage and VS conversion to biogas.

Figure 14. Algae digestion model - heat and energy analysis flow diagram

Figure 15. Heat required and head available for a digester fed $100 \%$ algae in two different climates (Sunnyvale, Calif. and Logan, Utah) 


\section{Introduction}

Wastewater treatment pond systems generally use less electricity and are less complex than common mechanical wastewater treatment systems, such as activated sludge (Downing et al., 2002; Middlebrooks et al., 1981). The lower electricity usage is achieved, in part, through the photosynthetic production of oxygen by algae, which can offset the need for mechanical aeration. However, some of this advantage in energy conservation is lost for wastewater pond systems that must use coagulation and separation processes to remove suspended microalgae from their effluent prior to discharge in order to meet regulations on total suspended solids (TSS) and fiveday biological oxygen demand $\left(\mathrm{BOD}_{5}\right)$. For example, the discharge limit established by the U.S. Environmental Protection Agency (USEPA) for treatment ponds is $45 \mathrm{mg} / \mathrm{L}$ for both $\mathrm{BOD}_{5}$ and TSS, on a 30-d average basis (EPA, 2007). After separation, the harvested algal biomass slurry is typically returned to the treatment ponds for disposal (Figure 1).

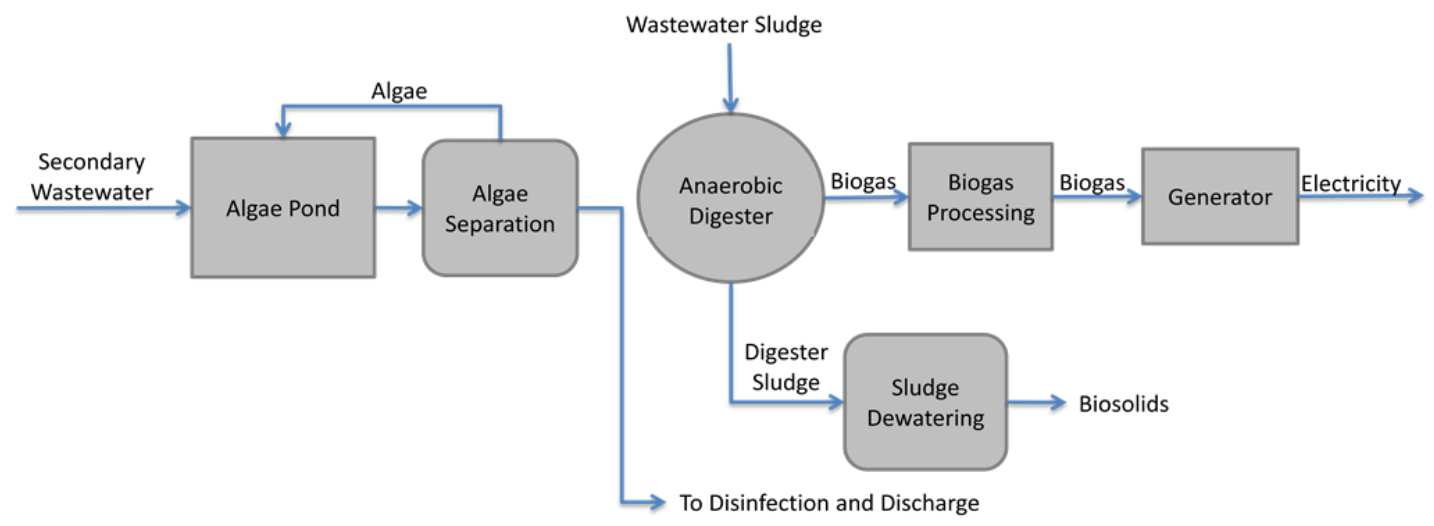

Figure 1. Schematic of a wastewater treatment pond process with primary clarification and algae separation

This practice leads to the need for more frequent dredging of the facultative ponds; release of oxygen-demanding substances and nutrients from the decomposing biomass; potentially increased emissions of the greenhouse gas methane; and the loss of the algae biomass, a potential biofuel feedstock. This conventional practice could be modified to include the anaerobic 
digestion of the algae (Figure 2), allowing wastewater treatment plants to increase production of renewable fuel (Oswald \& Golueke, 1960). Solar energy stored in algae cells as a result of photosynthesis can be converted into methane fuel through anaerobic digestion (Golueke et al., 1957). The methane can then be combusted to produce electricity, with waste heat used to heat the anaerobic digesters.

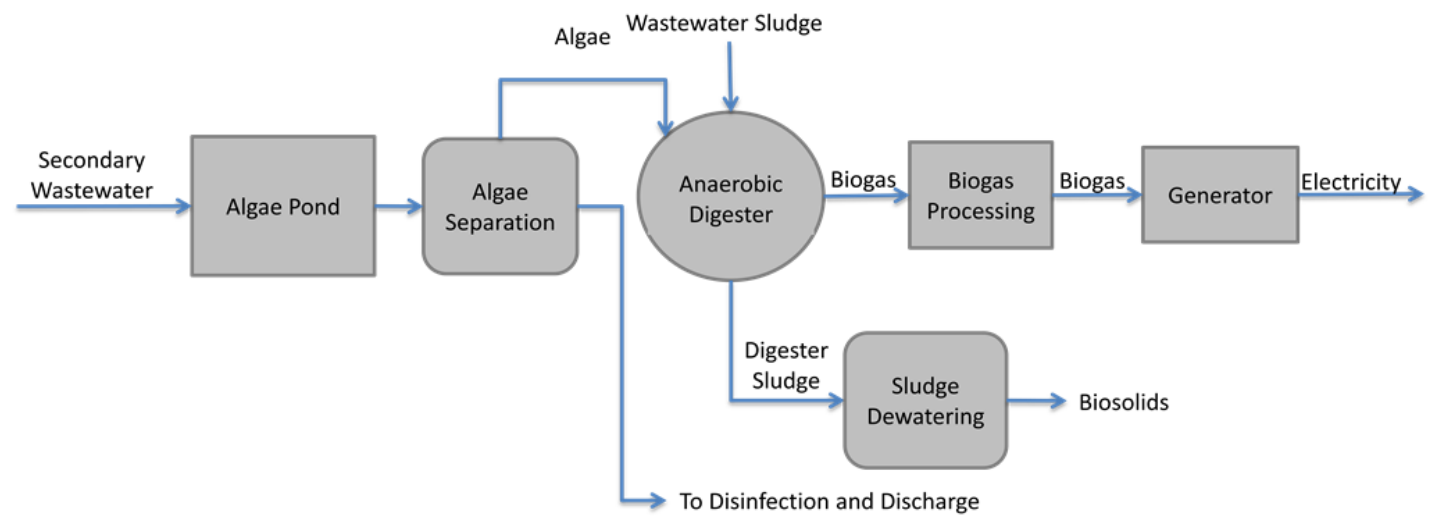

Figure 2. Schematic of a wastewater treatment pond process modified to include anaerobic digestion of the algae

As an example of a potential full-scale application of this concept, the Water Pollution Control Plant (WPCP) of the City of Sunnyvale, California is considering digestion of microalgae biomass, which is currently harvested from the effluent of 440 -acres of facultative ponds using polymer coagulation and dissolved air flotation. The harvested slurry, or float, is disposed of in the ponds. Previous attempts to digest this algae biomass at full-scale at Sunnyvale have been discontinued after a short time due to formation of a thick, stable algae float layer in the test digester and possible pH declines (EAO, Inc. \& Bracewell Engineering, Inc., 1988; De Sa, pers. comm., 2009)). To improve digester mixing and to minimize the formation of the float layer during future algae digestion trials, gas mixing of the digesters is being replaced with more effective external pump mixing. 
A barrier to widespread implementation of algae digestion is the resistant of algal biomass to anaerobic digestion (Golueke et al., 1957; Chen \& Oswald, 1998; Sialve et al., 2009). Algae have cell walls that resist degradation, and the biomass has a low carbon to nitrogen $(\mathrm{C} / \mathrm{N})$ ratio, approximately 6/1, compared to an ideal digester feed C/N ratio of 20/1 to 30/1 (Yen \& Brune, 2007). This low $\mathrm{C} / \mathrm{N}$ ratio can lead to high ammonia concentrations during digestion, which is inhibitory to methanogenic bacteria (Oswald \& Golueke, 1960). However, recent research has shown that algae digestion with high-carbon co-substrates can increase methane production, defined as the volume of methane produced per volume of digester per time (Yen \& Brune, 2007). Conceivably, the higher $\mathrm{C}: \mathrm{N}$ ratios provided by co-substrates could lead to improved methane yields from the algal biomass itself. One potential co-substrate is primary wastewater sludge, which has a $\mathrm{C} / \mathrm{N}$ ratio ranging from 6/1 to 16/1 (Tchobanoglous et al., 1993) and is available at wastewater treatment pond facilities with primary clarifiers. While this does not achieve the ideal $\mathrm{C} / \mathrm{N}$ ratio, the sludge is a more readily available, no-cost co-substrate, than potential alternatives such as food waste, fine sorted green waste, and waste paper.

The present research addresses $\mathrm{C}: \mathrm{N}$ ratio and additional concerns related to implementation of algae digestion: the maximum organic loading rate (OLR) that provides stable digestion at various ratios of algae/wastewater sludge in the digester feed, methane production rates, and digester effluent dewaterability as a function of algae content in the digester feed. Stable digestion is indicated by normal methane yields and solids destruction, healthy $\mathrm{pH}(6.6$-7.6) and steady production of biogas (McCarty, 1964).

The research described herein was part of a screening study conducted using laboratory digesters and microalgae collected from the Sunnyvale WPCP dissolved air flotation units. The purpose of this work was to explore the feasibility of algae digestion with wastewater sludge as a co-substrate, specifically: 
1. Investigate the potential increase in methane yield, defined as the amount of methane produced per gram of volatile solids added to the digester, through co-digestion of the algae with conventional wastewater sludge.

2. Evaluate the impact of organic loading rates (OLR) and hydraulic residence times (HRT) on the methane yield and production in algae anaerobic digestion.

3. Investigate the impact of algae digestion on the sludge dewatering process, as the efficiency of digester effluent dewatering significantly impacts the sludge disposal costs for wastewater treatment plants.

4. Develop an algae digestion facility model to determine the heating requirements and potential net energy benefit for the anaerobic digestion of wastewater pond algae.

Additional experiments on co-digestion of food waste with algae and wastewater sludge are to be reported elsewhere (Spierling, in preparation).

\section{Experimental Approach}

Co-digestion of wastewater algae and wastewater sludge was explored using ten 1-L digesters in two experimental runs. Each digester was named for the experimental run (1 or 2) and the digester number (1 through 10). The digesters were fed slurries consisting of different proportions and concentrations of wastewater pond algae and wastewater treatment plant sludge to control OLR, HRT, and the algae/sludge ratio (volatile solids based). In Experiment \#1, different algae/sludge ratios (Digester \#1-1 through \#1-10) were tested, and in Experiment \#2, several levels of OLR (Digesters \#2-1 through\# 2-10) and HRT (Digester \#2-10) were tested (Table 1). 
Table 1: Experimental design for anaerobic co-digestion of algae biomass and wastewater sludge

\begin{tabular}{cccccc}
\hline Experiment & Digester Name & $\begin{array}{c}\text { Algae Fraction } \\
\text { (g VS/g VS) }\end{array}$ & $\begin{array}{c}\text { Sludge Fraction } \\
\text { (g VS/g VS) }\end{array}$ & $\begin{array}{c}\text { OLR } \\
\text { (g VS/L-d) }\end{array}$ & $\begin{array}{c}\text { HRT } \\
(\mathrm{d})\end{array}$ \\
\hline 1 & $1-1$ & 100 & 0 & 2 & 20 \\
1 & $1-2$ & 100 & 0 & 2 & 20 \\
1 & $1-5$ & 0 & 100 & 2 & 20 \\
1 & $1-6$ & 20 & 80 & 2 & 20 \\
1 & $1-7$ & 40 & 60 & 2 & 20 \\
1 & $1-8$ & 60 & 40 & 2 & 20 \\
1 & $1-9$ & 80 & 40 & 2 & 20 \\
1 & $1-10$ & 100 & 0 & 4 & 20 \\
2 & $2-1$ & 100 & 0 & 4 & 20 \\
2 & $2-2$ & 80 & 20 & 2 & 20 \\
2 & $2-3$ & 80 & 20 & 4 & 20 \\
2 & $2-4$ & 80 & 20 & 1 & 40 \\
2 & $2-10^{*}$ & & 00 & 20 & 20 \\
\hline
\end{tabular}

* Digester was operated $2.9^{\circ} \mathrm{C}$ warmer than the other digesters for part of the data collection period. See text below.

The digesters were constructed with 2-L Erlenmeyer flasks, each equipped with ports for extraction of effluent, the introduction of feed, and the collection of biogas. Barbed plastic tubing connectors, placed in holes drilled into butyl rubber stoppers and connected to vinyl tubing were used to seal the digesters and connect the feeding and withdrawal syringes. The flasks were maintained at a mesophilic temperature of $37.5 \pm 1{ }^{\circ} \mathrm{C}$ with one exception. An excursion to $40.4^{\circ} \mathrm{C}$, due to an unrepairable incubator malfunction, lasted approximately 1 month but affected only Digester \#2-10. Approximately 50\% of the Digester \#2-10 data was collected in this period. Digester effluent withdrawal, feed introduction, and biogas measurement were performed daily. Alkalinity and $\mathrm{pH}$ measurements were made on each day's effluent samples. Weekly determinations on digester feed and effluent were made for concentrations of solids, total carbon, total nitrogen, total ammonia nitrogen $\left(\mathrm{TAN} ; \mathrm{NH}_{4}{ }^{+}+\mathrm{NH}_{3}\right.$ as $\left.\mathrm{N}\right)$, and volatile fatty acids. 
The biogas produced was collected in an inverted 2-L transparent polymethylpentene graduated cylinder submerged in a $5 \%(\mathrm{v} / \mathrm{v})$ sulfuric acid solution saturated with sodium chloride and tinted with Congo Red. The graduated cylinders were connected to the digesters with Tygon B-44-3 tubing using barbed tubing connectors sealed with silicone caulking. The volume of biogas collected was measured daily after lifting the graduated cylinder until the internal and external liquid levels were equal. The biogas was then released to provide capacity for the next day's biogas production. The gas collectors were maintained at the same temperature as the digesters, $37.5^{\circ} \mathrm{C}$. The biogas production rates reported were at atmospheric pressure and $37.5^{\circ} \mathrm{C}$. Biogas composition was measured weekly.

In Experiment \#1, the initial contents of Digesters \#1-1 through \#1-10 consisted of City of San Luis Obispo Water Reclamation Facility (WRF) digester effluent (36\%) and digester contents from previous algae digestion experiments (64\%). For Experiment \#2, the initial contents of Digesters \#2-1 through\# 2-10 comprised of Experiment \#1 algae digester contents (91\%) and WRF digester effluent (8\%). In each case, the residual digester contents from the previous algae digestion experiments were blended together and redistributed to the digesters along with the WRF digester effluent. The headspace of the digesters was then filled with nitrogen gas. The WRF digester effluent was collected from the second digester in a series of three at the facility.

The algal biomass used in the experiments was collected in 140-L batches from the City of Sunnyvale Water Pollution Control Plant (California), which operates primary clarifiers followed by facultative treatment ponds, nitrifying biotowers, coagulation with cationic polyelectrolyte polymer, and DAF clarifiers. Treated effluent is discharged to San Francisco Bay, and the algae biomass is disposed of in one of the ponds. The algae biomass used in the experiments was DAF float collected from the one of the DAF float troughs. When collected, the float contained $\sim 5 \%$ total solids. The biomass was then transported overnight in un-refrigerated 20 -L plastic pails. By the morning, additional separation had occurred, and the float could be decanted, resulting in $12 \%$ 
total solids content. After decanting, the biomass was thoroughly homogenized in a plastic wheelbarrow with a hoe and distributed into 1-L zipper-lock plastic bags and frozen at ${ }^{-} 20^{\circ} \mathrm{C}$. The methane potential of unfrozen biomass was compared to that of frozen biomass in an experiment described elsewhere (Spierling, in progress). The wastewater sludge used in the experiments consisting of approximately $65 \%$ waste activated sludge and the remainder was a mixture of primary and trickling filter sludge. This sludge mixture was collected from the WRF dissolved air flotation thickener (DAFT) and immediately homogenized and stored using the same procedure that was used with the algae.

Prior to feeding, the algae and sludge were thawed, diluted, and blended with a magnetic stir bar to obtain the desired proportions and solids concentrations. Batches of prepared feed were then stored at $4^{\circ} \mathrm{C}$ and used within 7 days. The feeding process involved stirring a digester by vigorously swirling the flask for 60 seconds and removing the appropriate volume of representative digester contents using a $60-\mathrm{mL}$ plastic syringe. Then, feed was then injected into the digester using a $60-\mathrm{mL}$ syringe. The volumes exchanged were $25 \mathrm{~mL}$ or $50 \mathrm{~mL}$, depending on the target HRT and the digester volume. The digesters were then sealed using tubing clamps and swirled for approximately 60 seconds.

During the effluent withdrawal, approximately $5 \mathrm{~mL}$ of digester contents were lost due to leakage at the tubing-syringe connection. To maintain the liquid level in the digesters, the amount effluent withdrawn with the syringe was decreased to account for the leakage. In each experiment, all of the digesters were operated for approximately $60 \mathrm{~d}$ to allow them to approach steady-state. For all digesters except Digester \#2-10, this was approximately three hydraulic residence times. However, Digester \#2-10 (40-d HRT) was only operated for approximately 1.5 hydraulic residence times. 


\section{Analytical Methods}

The $\mathrm{pH}$ of digester effluent and feed samples was measured with a gel-type electrode and meter. Prior to each use, the electrode underwent a three-point calibration. The electrode was conditioned or replaced as needed to ensure stable readings.

Total alkalinity was determined by titration per Method 2320 B (APHA, 2005), with the exception that $0.5-\mathrm{N}$ sulfuric acid was used to reach a $\mathrm{pH}$ endpoint of 4.5. Each titration was completed within approximately $2 \mathrm{~min}$.

Volatile fatty acid (VFA) concentrations were determined by chromatography per Method 5560 B (APHA, 2005). Prior to analysis, the digester effluent samples were centrifuged in 50-mL centrifuge tubes for 2 minutes at maximum speed in a clinical benchtop centrifuge (IEC, Boston, Mass.) and decanted to extract the supernatant. Separate clean beakers were needed for each sample to prevent VFA carryover.

Total ammonia nitrogen (TAN, $\mathrm{NH}_{4}^{+}+\mathrm{NH}_{3}$ ) concentrations were measured using an ion selective electrode per Methods 4500 (APHA, 2005). Due to the high concentrations of TAN, most digester effluent samples were diluted (5:1) prior to analysis. For each sample run, an ammonia calibration curve was developed using dilutions of a $2058 \mathrm{mg} / \mathrm{L} \mathrm{NH}_{3}-\mathrm{N}$ standard.

Matrix spike samples were tested to detect matrix interferences for VFA and TAN analysis per Method 4020 B, (APHA, 2005). Each batch of samples analyzed included one matrix spiked sample and one commercially-prepared standard. Matrix spike recoveries outside of $10 \%$ were repeated if possible. For TAN analysis, a $2058 \mathrm{mg} / \mathrm{L} \mathrm{NH}_{3}-\mathrm{N}$ standard was used for the TAN matrix and standard analysis. Recovery for TAN matrix spiked samples was consistently within $15 \%$ and did not require re-analyses. For the VFA analysis, a $500 \mathrm{mg} / \mathrm{L}$ acetic acid standard was used for matrix and standards analysis, and one de-ionized water sample was tested for sample blank analysis. Matrix spike recoveries for VFA analysis exceeded $15 \%$ in approximately one 
third of the analysis batches due to the difficulty obtaining accurate measurements at low concentrations $(\sim 500 \mathrm{mg} / \mathrm{L})$ with the chromatographic method.

Biogas composition was determined with a SRI 8610 gas chromatograph (Torrance, Calif.). Biogas was extracted through a septum port in each gas collector using a 1-mL syringe. To prevent contamination with air, the syringe was continuously ejected at a low rate during the transfer to the gas chromatograph, which was in the same room as the digesters.

To determine carbon and nitrogen content in dry solids and to track volatile solids destruction, total and volatile solids (VS) were measured weekly per Methods 2540 B (APHA, 2005). Samples of digester effluent and feed were mixed on a magnetic stir plate, and representative samples were collected with a modified 3-mL plastic syringe and dispensed into tared aluminum trays. The narrow tip of the syringe was cut off to allow for the passage of solids.

Nitrogen and organic carbon content of total solids were determined with an Elementar Vario Max instrument configured for simultaneous carbon and nitrogen analysis. To prepare the digester feed and effluent samples, $\mathrm{pH}$ was lowered to 4.5 with sulfuric acid to limit ammonia volatilization, and then the samples were dried at $55^{\circ} \mathrm{C}$ for $3 \mathrm{~d}$. The dried samples were ground with a mortar and pestle and stored in a desiccator until analysis was performed. The Vario Max operated at $1200^{\circ} \mathrm{C}$ with three catalytic combustion tubes filled with quartz wool, corundum balls, copper oxide, platinum catalyst, silver wool, and tungsten. $\mathrm{A} \mathrm{CO}_{2}$ absorption column separated the carbon and nitrogen prior to being analyzed in a thermal conductivity detector, which quantified the amount of carbon and nitrogen in each sample. Glutamic acid $(9.52 \%$ Nitrogen and $40.78 \%$ Carbon) and NIST Standard 1573a Tomato leaves (certified 3.03\% Nitrogen and $\sim 36.2 \%$ Carbon) were used to confirm the instrument accuracy. 
To calculate the carbon mass balance, the total solids (TS) concentration and the organic carbon fraction of the feed were used to calculate the amount of organic carbon entering and exiting the digesters. The amount of inorganic carbon, in the form of carbonate species, entering and exiting the digesters was calculated using the following equilibrium equations (Sawyer et al., 2002):

$$
\begin{gathered}
{\left[\mathrm{HCO}_{3}^{-}\right]=\frac{\text { Alkalinity }\left(\frac{e q}{L}\right)-\frac{K_{w}}{\left[H^{+}\right]}+\left[H^{+}\right]}{1+\frac{2 * K_{A 2}}{\left[H^{+}\right]}}} \\
{\left[\mathrm{CO}_{3}^{2-}\right]=\frac{0.5 * \text { Alkalinity }\left(\frac{e q}{L}\right)-\frac{K_{w}}{\left[H^{+}\right]}+\left[H^{+}\right]}{1+\frac{\left[H^{+}\right]}{2 * K_{A 2}}}}
\end{gathered}
$$

where $\mathrm{K}_{\mathrm{w}}$ and $\mathrm{K}_{\mathrm{A} 2}$ are the usual equilibrium constants. No correction was made for ion activity. Carbon in the form of dissolved methane was estimated using Henry's law, with the Henry's law constant for methane of $769 \mathrm{~L}-\mathrm{atm} / \mathrm{mol}$. The mass balance method is discussed further in Section 4.5 .

The dewaterability of algae digester effluent compared to conventional wastewater sludge digester effluent was determined using a lab-scale test meant to simulate belt press dewatering. The algae digester effluent samples were mixed with a polyelectrolyte polymer at a typical wastewater sludge thickener dosage of $5 \mathrm{~g}$ polymer $/ \mathrm{kg}$ TS (Tchobanoglous et al., 2003). The polymer used was the same as that used to harvest the algae at Sunnyvale, namely, Clarifloc WE717 (SNF Polydyne, Atlanta, Ga.), a water-soluble cationic polyelectrolyte. The wastewater sludge digester effluent, obtained from the second digester in series at the WRF, required a higher concentration of the polymer (15 g polymer/kg TS) to achieve visible flocculation.

To prepare the mixtures, the neat polymer was diluted 1:100 (mass basis) in reverse osmosis water while being mixed vigorously with a magnetic stir bar. After approximately 2 minutes of 
mixing, the diluted polymer was then added to a 20 -mL digester effluent sample and mixed using a magnetic stir bar for an additional 2 minutes. The mixture was then poured onto a Millipore filter stainless steel support screen (125-micron mesh size). A vacuum (10.5 psi) was applied for approximately 1 minute to separate the water from the solids. The volume of water withdrawn and the solids content of the retained sludge was then measured and used as a relative measure of dewaterability.

\section{Results}

The results obtained from the algae co-digestion experiments are divided into six sections. Section 4.1 covers steady-state digester results, including determination of steady-state conditions, methane yield and volumetric production, and digester stability. Section 4.2 covers the impact of algae/sludge ratio on methane yield. Sections 4.3 and 4.4 cover the effect of organic loading rate and hydraulic residence time on methane yield and production. Section 4.5 covers the carbon mass balance, and Section 4.6 covers algae digester effluent dewatering. The digester heating and energy model is discussed in Section 5.

\subsection{Steady-State Digester Operation}

The digesters were operated for 60 days, which for the 20-d HRT digesters, was about three HRTs. During Experiment \#1, the levels of several independent variables became relatively steady in less than three residence times: $\mathrm{pH}$, alkalinity, methane yield, and methane production. The steady-state periods used in subsequent data analysis were selected based on these independent variables (e.g., Figure 3). However, volatile solids destruction, in particular, did not reach steady-state within three HRTs in the digesters with low algae/sludge ratios. Digesters with low algae content in the feed showed an increase in volatile solids destruction as the experiment progressed (Figure 4). 

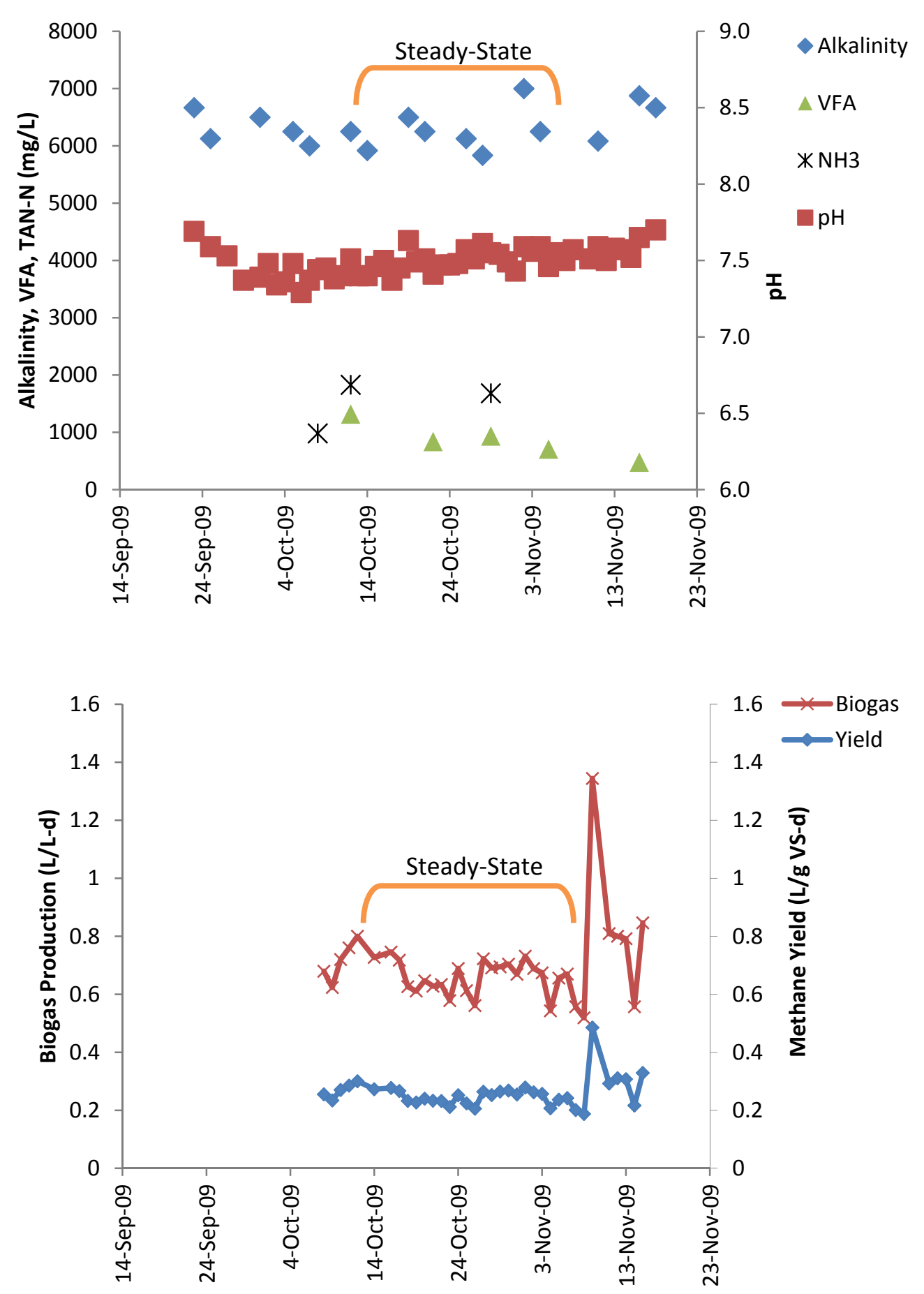

Figure 3. The steady-state period selected for data analysis for Digester \#1-1 (100\% Algae, OLR $2 \mathrm{~g}$ VS/L-d, HRT 20 d) is representative of the steady-state period for the other digesters. The spike in biogas production in November was potentially caused a deviation in the daily schedule of biogas production measurements. 


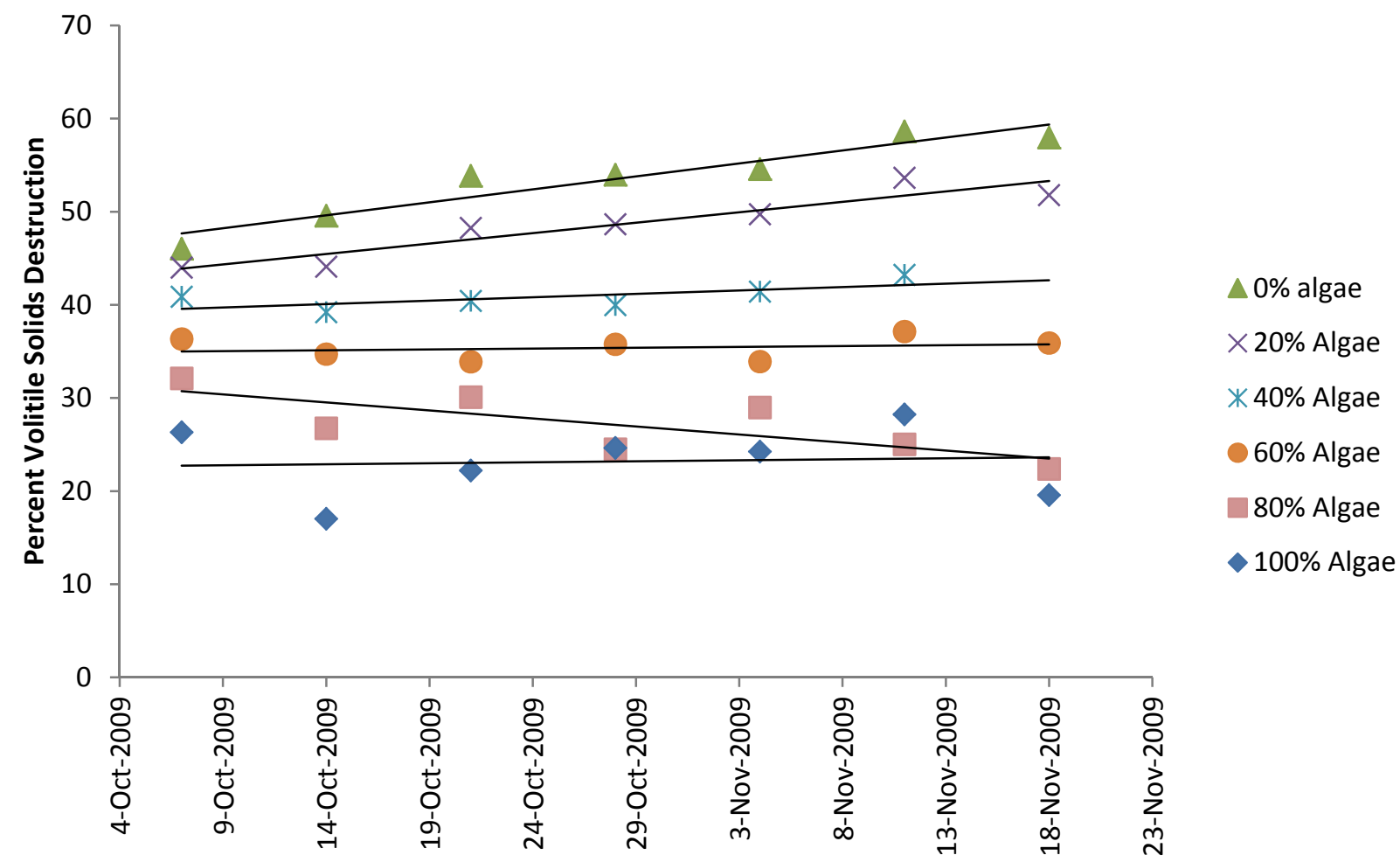

Figure 4. Volatile solids destruction in Experiment \#1 did not stabilize in digesters with low algae/sludge ratios.

In Experiment \#2, the period of time that some digesters operated at steady-state was shorter than Experiment \#1, due to the instability discussed further in Section 5.2. The steady-state periods selected for Experiment \#2 were $\sim 4$ weeks in which $\mathrm{pH}$, alkalinity, VS destruction, and biogas production in each digester exhibited the least variation. All of the analytical results for the steady-state period of each digester were averaged to provide a single value for each variable in each experiment (Table 2). 
Table 2. Mean values for each digester during its steady-state operating period.

\begin{tabular}{|c|c|c|c|c|c|c|c|c|}
\hline $\begin{array}{l}\text { Digester } \\
\text { Number }\end{array}$ & $\mathrm{pH}$ & $\begin{array}{c}\text { Alkalinity } \\
(\mathrm{mg} / \mathrm{L} \text { as } \\
\left.\mathrm{CaCO}_{3}\right)\end{array}$ & $\begin{array}{c}\text { VFA } \\
\text { (mg/L as } \\
\text { acetic acid) }\end{array}$ & $\begin{array}{c}\text { TAN } \\
(\mathrm{mg} / \mathrm{L} \text { as } \mathrm{N})\end{array}$ & $\begin{array}{c}\text { Methane } \\
\text { Content } \\
(\%)\end{array}$ & $\begin{array}{l}\mathrm{CH}_{4} \text { Yield } \\
\text { (L/g VS-d) }\end{array}$ & $\begin{array}{c}\mathrm{CH}_{4} \\
\text { Production } \\
\text { (L/L-d) }\end{array}$ & $\begin{array}{c}\mathrm{VS} \\
\text { Destruction }^{2} \\
(\%)\end{array}$ \\
\hline $1-1$ & 7.51 & 6341 & 857 & 1497 & 75 & 0.26 & 0.52 & 25 \\
\hline $1-2$ & 7.50 & 6345 & 802 & 1565 & 76 & 0.26 & 0.52 & 29 \\
\hline $1-5$ & 7.33 & 5778 & 413 & 1093 & 68 & 0.44 & 0.87 & 57 \\
\hline $1-6$ & 7.41 & 5875 & 202 & 1249 & 70 & 0.42 & 0.85 & 52 \\
\hline $1-7$ & 7.44 & 5951 & 202 & 1323 & 72 & 0.40 & 0.81 & 42 \\
\hline $1-8$ & 7.50 & 5988 & 170 & 1341 & 73 & 0.36 & 0.73 & 38 \\
\hline $1-9$ & 7.49 & 6102 & 122 & 1396 & 73 & 0.36 & 0.72 & 35 \\
\hline $1-10$ & 7.46 & 6341 & 857 & 928 & 72 & 0.30 & 0.60 & 31 \\
\hline $2-1$ & 7.61 & 11239 & 4596 & 3355 & 69 & 0.21 & 0.85 & 27 \\
\hline $2-2$ & 7.78 & 10481 & 3573 & 3449 & 69 & 0.24 & 0.95 & 33 \\
\hline $2-3$ & 7.55 & 6130 & 210 & 1541 & 74 & 0.28 & 0.57 & 43 \\
\hline $2-4$ & 7.74 & 10685 & 2499 & 3241 & 69 & 0.26 & 1.03 & 29 \\
\hline $2-10^{3}$ & 7.63 & 7296 & 404 & 2175 & 67 & 0.27 & 0.27 & 39 \\
\hline
\end{tabular}

${ }^{1}$ Units of $\mathrm{CH}_{4}$ production are liters of $\mathrm{CH}_{4}$ produced per liter of digester per day

${ }^{2} \mathrm{VS}$ destruction did not reach steady-state during the course of the experiments for digesters with low algae/sludge ratios in the feed. See Figure 4.

${ }^{3}$ Digester was operated $2.9^{\circ} \mathrm{C}$ warmer than the other digesters for part of the data collection period.

\subsection{Algae/Sludge Ratio (Experiment \#1)}

The focus of Experiment \#1 was the relationship between the algae/sludge ratio and the digester stability and methane yield. In Experiment \#1, all the digesters were operated at a consistent OLR of $2 \mathrm{~g} \mathrm{VS/L-day} \mathrm{with} \mathrm{a} \mathrm{20-day} \mathrm{HRT,} \mathrm{and} \mathrm{they} \mathrm{operated} \mathrm{without} \mathrm{significant} \mathrm{upsets}$ to $\mathrm{pH}$, alkalinity, VFA, TAN, and biogas production. The stability of Digester \#1-1 is representative of all the digesters in Experiment \#1 (Figure 3).

Methane yield and methane production values for each algae/sludge feed ratio were developed using the steady-state biogas production and biogas composition values from Experiment \#1 (Figure 5). The methane yield for the 100\% algae digesters operating at an OLR of $2 \mathrm{~g} / \mathrm{L}-\mathrm{d}$ and an HRT of 20 days was $0.26 \mathrm{~L} / \mathrm{g}$ VS. This methane yield was within the rather large range of methane yields seen in other algae digestion studies of 0.09 to $0.45 \mathrm{~L} / \mathrm{g}$ VS (Sialve et al., 2009). The methane yield for the $100 \%$ sludge (i.e., $0 \%$ algae) digester, operating under 
the same conditions, was $0.44 \mathrm{~L} / \mathrm{g}$ VS introduced or $69 \%$ higher than the $100 \%$ algae digesters. A linear relationship was observed between the algae/sludge ratio and both methane yield and methane production; $\mathrm{r}^{2}=0.94$ (Figure 5).

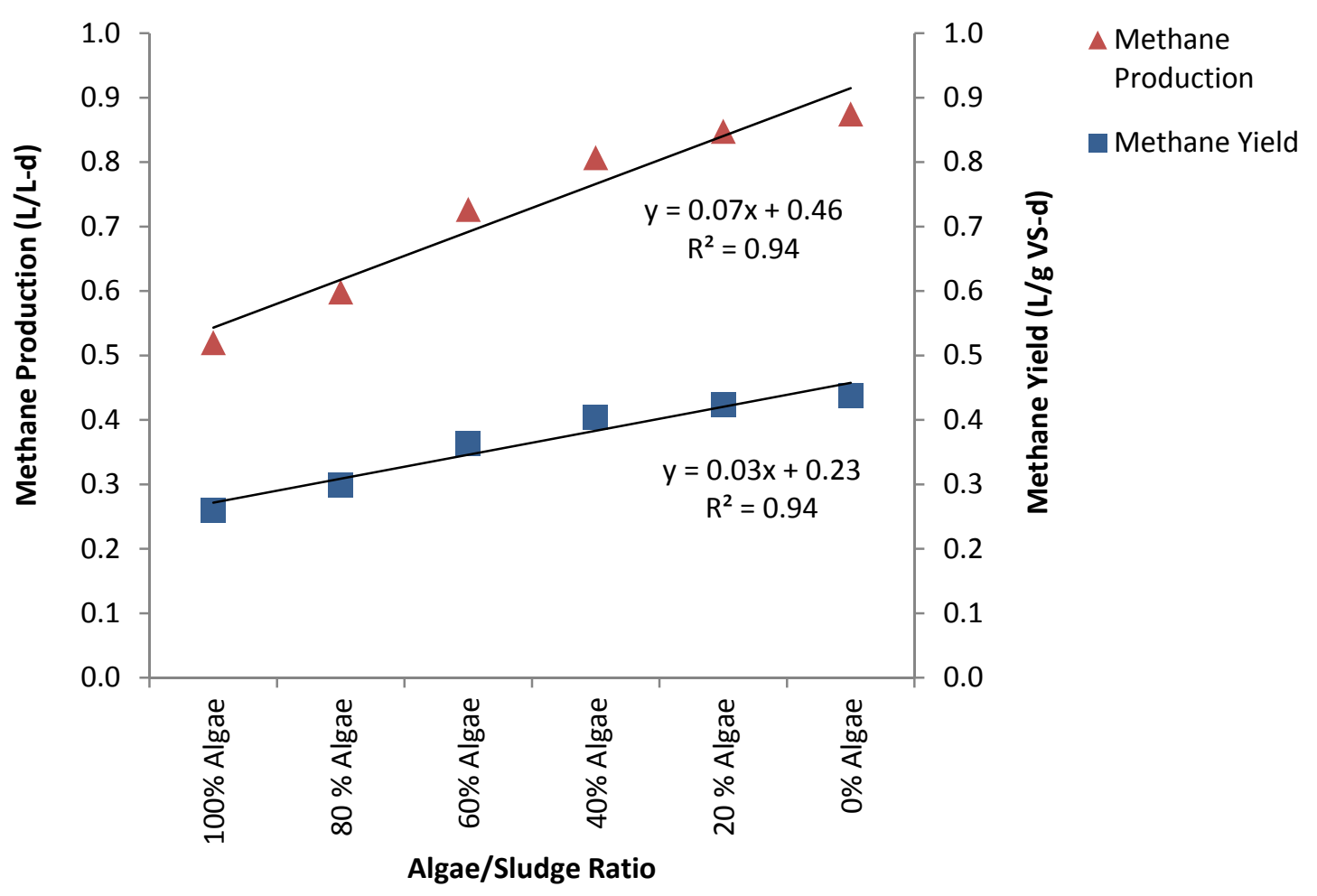

Figure 5. Effect of algae/sludge ratio on methane production rate and yield

The relationship between volatile solids destruction and algae/sludge ratio was also linear.

The mean volatile solids destruction for the $100 \%$ algae digesters, operating at a 20 -d HRT and a $2 \mathrm{~g} \mathrm{VS} / \mathrm{L}-\mathrm{d}$ OLR was $23 \%$, and for the $0 \%$ algae (i.e., $100 \%$ sludge) digester operating the same OLR and HRT, it was 54\% (Figure 6). 


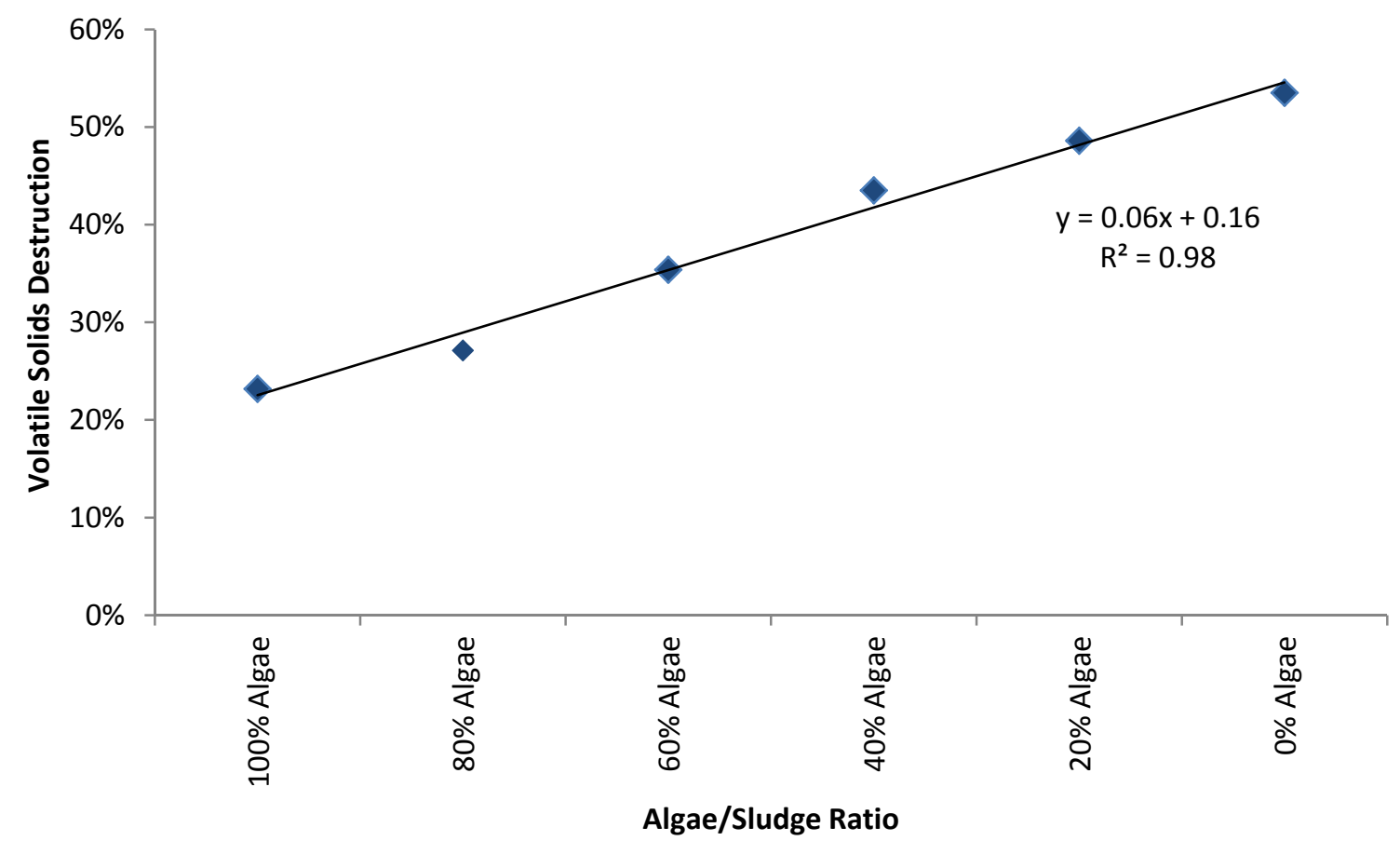

Figure 6. Relationship between mean volatile solids destruction and the algae/sludge ratio

\subsection{Organic Loading Rate (Experiment \#2)}

Experiment \#2 explored the impact of OLR on methane yield, methane production, and volatile solids destruction. The methane yield for $100 \%$ algae digesters operating at $4 \mathrm{~g} \mathrm{VS} / \mathrm{L}-\mathrm{d}$ OLR was $12 \%$ lower than those operating at $2 \mathrm{~g} \mathrm{VS} / \mathrm{L}-\mathrm{d}$ OLR $(0.23 \mathrm{~L} / \mathrm{g}$ VS-d compared to 0.26

L/g VS-d; Figure 7). However, in terms of methane production, the $100 \%$ algae digesters operating at an OLR of $4 \mathrm{~g}$ VS/L-d had 73\% higher methane production than digesters operating at an OLR of $2 \mathrm{~g} \mathrm{VS} / \mathrm{L}-\mathrm{d}(0.90 \mathrm{~L} / \mathrm{L}-\mathrm{d}$ compared to $0.52 \mathrm{~L} / \mathrm{L}-\mathrm{d}$; Figure 8). 


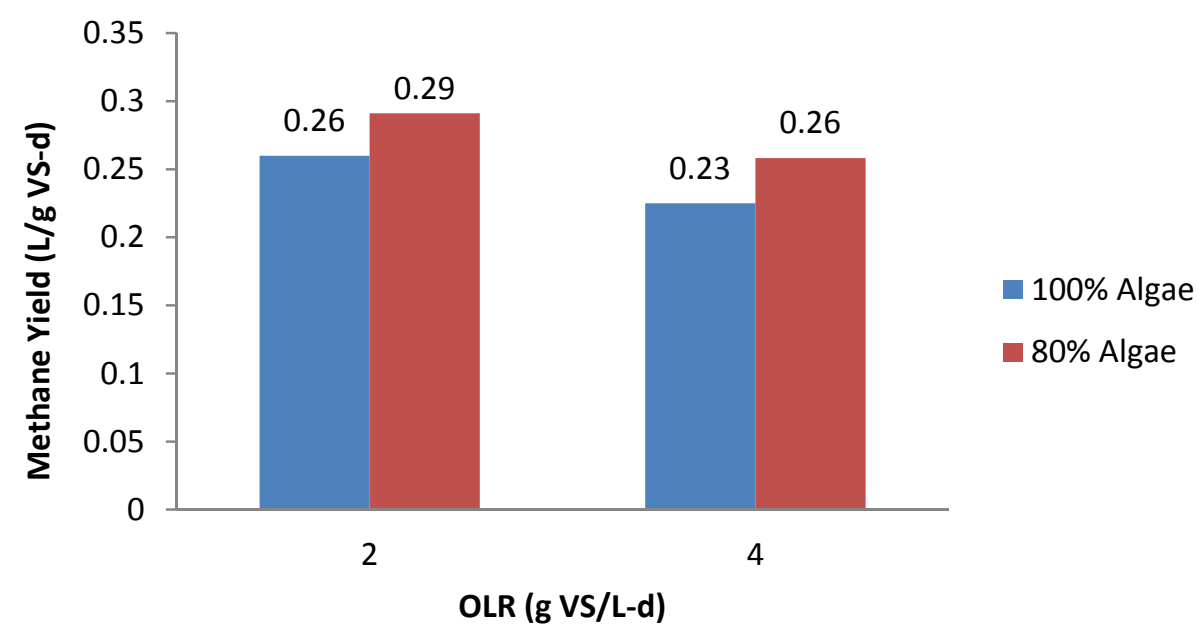

Figure 7. Methane yield vs. OLR for $100 \%$ and $80 \%$ algae digesters operated at an HRT of 20 days

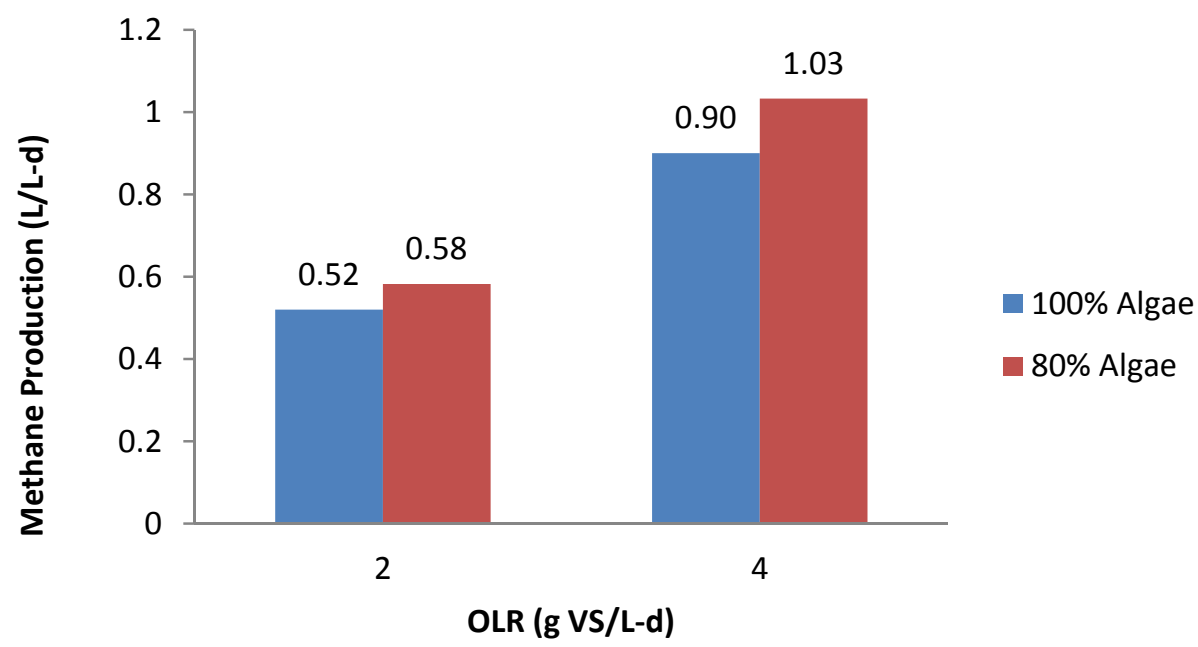

Figure 8. Methane production vs. OLR for $100 \%$ and $80 \%$ algae digesters operated at an HRT of 20 days 


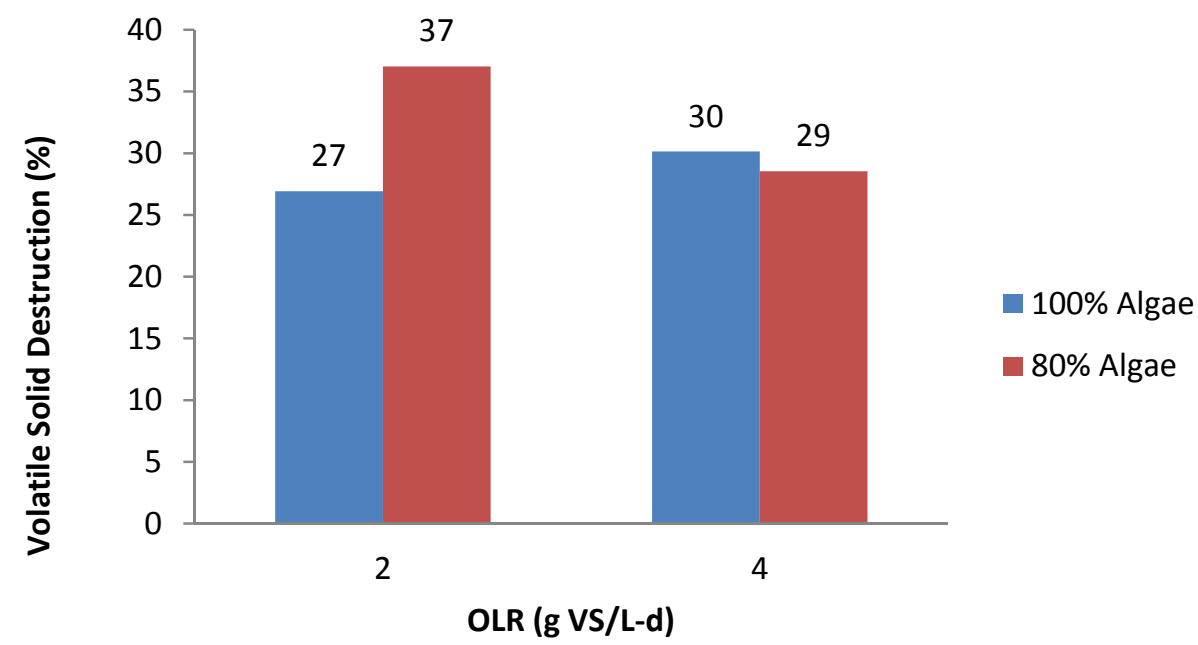

Figure 9. Volatile solids destruction vs. OLR for $100 \%$ and $80 \%$ algae digesters operated at an HRT of 20 days

The volatile solids destruction data were inconclusive. For the $100 \%$ algae digesters, the volatile solids destruction was higher at the higher OLR: $30 \%$ at a $4 \mathrm{~g}$ VS/L-d OLR compared to $27 \%$ at a $2 \mathrm{~g} \mathrm{VS} / \mathrm{L}-\mathrm{d}$. However, for the $80 \%$ algae digester, the volatile solids destruction was lower at the higher OLR: $37 \%$ at a $4 \mathrm{~g}$ VS/L-d OLR compared to $29 \%$ at a $2 \mathrm{~g}$ VS/L-d OLR (Figure 9).

\subsection{Hydraulic Residence Time (Experiment \#2)}

Experiment \#2 explored the impact of HRT on methane yield, methane production, and VS destruction. Two digesters operating at different digester volumes, but fed the same substrate ( $80 \%$ algae, $40 \mathrm{~g} \mathrm{VS} / \mathrm{L}$ ), were used to explore the benefit of additional digester residence time and decreased OLR on methane yield, production, and VS destruction. In the digester operated at an HRT of 40 days and a $1 \mathrm{~g} \mathrm{VS/L-d} \mathrm{OLR,} \mathrm{the} \mathrm{methane} \mathrm{yield} \mathrm{was} 0.27 \mathrm{~L} / \mathrm{g}$ VS-d, approximately equal to the $0.28 \mathrm{~L} / \mathrm{g}$ VS-d yield measured in the digester operated at a HRT of 20 days and a $2 \mathrm{~g}$ VS/L-d OLR (Figure 10). Methane yield did not increase despite the doubling of the HRT, halving the OLR, and operating at a higher temperature. Approximately $50 \%$ of the steady state 
data for Digester \#2-10 (40-d HRT) was collected while the incubator was malfunctioning and operating $2-3^{\circ} \mathrm{C}$ above $37.5^{\circ} \mathrm{C}$. Methane production for the 40-day HRT digester was significantly lower: $0.27 \mathrm{~L} / \mathrm{L}-\mathrm{d}$ compared to $0.57 \mathrm{~L} / \mathrm{L}-\mathrm{d}$ at the shorter HRT, a $53 \%$ difference. VS destruction was 10\% lower at the longer HRT, 39\% compared to $43 \%$.

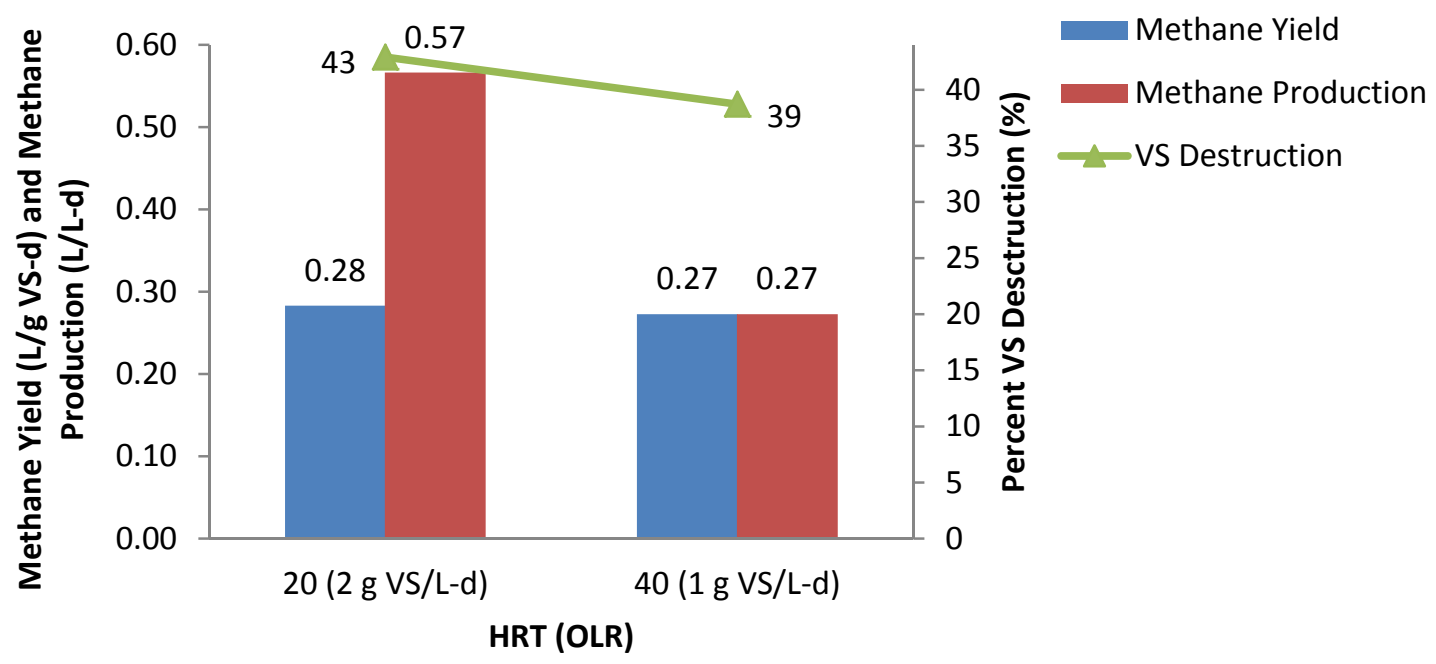

Figure 10. Effect of hydraulic residence time on methane yield, methane production, and volatile solids destruction in $80 \%$ algae digesters operated at two different OLR

\subsection{Carbon Mass Balance}

To ensure the validity of the methane yield and production data, carbon mass balances were performed on each of the digesters during their steady-state period (Equation 1). Using the measured and calculated carbon mass balance results, the carbon exiting the digesters in the form of biogas and effluent was within $10 \%$ of the carbon fed the digesters. These data verified that any leakage of biogas out of the experimental apparatus was insignificant and that the methane yield and production data obtained from the experiment was valid (Table 3).

$$
\begin{aligned}
& (\text { Organic } \mathrm{C}+\text { Dissolved Inorganic C })_{\text {Liquid In }}= \\
& (\text { Organic C }+ \text { Dissolved Inorganic C })_{\text {Liquid Out }}+\left(\mathrm{CH}_{4}+\mathrm{CO}_{2}\right)_{\text {Biogas Out }}
\end{aligned}
$$


Table 3. Carbon mass balance results for the steady-state periods. All values are g C/d.

\begin{tabular}{|c|c|c|c|c|c|c|}
\hline \multirow{4}{*}{$\begin{array}{l}\text { Digester } \\
\text { Number }\end{array}$} & \multicolumn{4}{|c|}{ Liquid Mass Flows } & \multicolumn{2}{|l|}{ Biogas Mass Flow } \\
\hline & $\begin{array}{l}\text { Organic } \\
\text { Carbon }\end{array}$ & & $\begin{array}{l}\text { Organic } \\
\text { Carbon }\end{array}$ & $\begin{array}{l}\text { Inorganic } \\
\text { Carbon \& } \\
\text { Dissolved }\end{array}$ & & \\
\hline & Loading & Inorganic Carbon & Exit & $\mathrm{CH}_{4}$ Exit & Biogas Carbon & \\
\hline & Rate & Loading Rate & Rate & Rate & Exit Rate & Difference \\
\hline $1-1$ & 1.09 & 0.02 & 0.70 & 0.10 & 0.33 & -0.03 \\
\hline $1-2$ & 1.09 & 0.02 & 0.68 & 0.10 & 0.32 & 0.01 \\
\hline $1-5$ & 1.00 & 0.02 & 0.43 & 0.09 & 0.60 & -0.09 \\
\hline $1-6$ & 1.02 & 0.02 & 0.45 & 0.09 & 0.57 & -0.07 \\
\hline $1-7$ & 1.04 & 0.02 & 0.51 & 0.09 & 0.53 & -0.07 \\
\hline $1-8$ & 1.06 & 0.02 & 0.57 & 0.09 & 0.47 & -0.06 \\
\hline $1-9$ & 1.06 & 0.02 & 0.59 & 0.10 & 0.47 & -0.07 \\
\hline $1-10$ & 1.07 & 0.02 & 0.63 & 0.10 & 0.39 & -0.03 \\
\hline $2-1$ & 1.07 & 0.02 & 0.67 & 0.10 & 0.29 & 0.01 \\
\hline $2-2$ & 1.07 & 0.02 & 0.70 & 0.10 & 0.32 & -0.03 \\
\hline $2-3$ & 0.53 & 0.01 & 0.28 & 0.06 & 0.19 & 0.02 \\
\hline $2-4$ & 1.02 & 0.02 & 0.69 & 0.10 & 0.34 & -0.08 \\
\hline $2-10$ & 0.52 & 0.01 & 0.28 & 0.07 & 0.54 & -0.01 \\
\hline
\end{tabular}

\subsection{Algae Digester Dewatering}

Dewatering experiments were performed on the effluent from Digesters \#2-1, \#2-2, \#2-3, and \#2-4 and on the effluent from the WRF secondary digester to compare the effectiveness of dewatering procedures on algae digester effluent with wastewater sludge digester effluent (Figure 11). The total solids (TS) concentrations in the digester effluent were then compared to the dewatered TS concentrations to evaluate the effectiveness of the dewatering. 


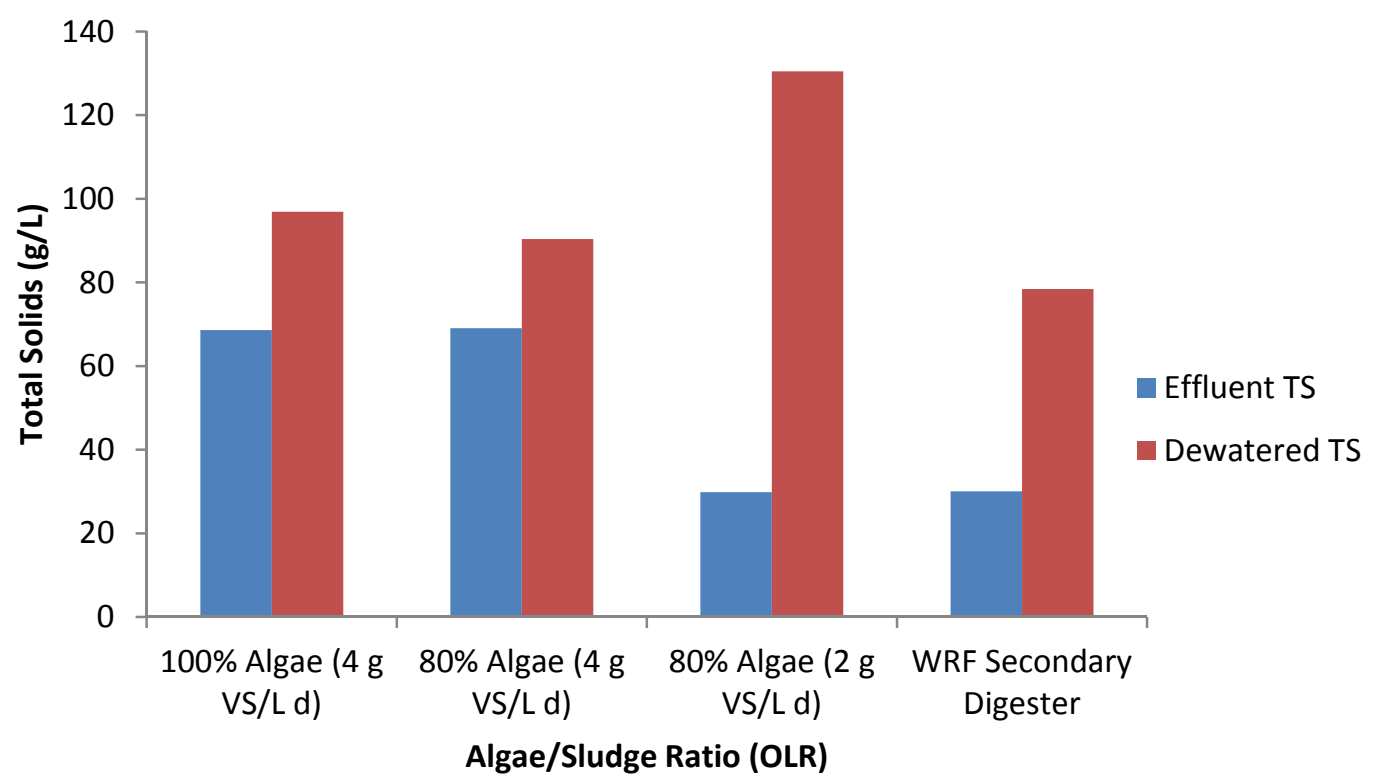

Figure 11. Comparison of dewatering of algae digester and wastewater sludge digester effluent. WRF Digester 2 effluent required triple the concentration of polymer compared to algae digester effluent. The feed for algae digesters was frozen prior to being digested.

\section{Discussion}

\subsection{Algae/Sludge Ratio (Experiment \#1)}

The results indicated algae co-digestion was feasible and stable for a $2 \mathrm{~g}$ VS/L-d OLR and a $20 \mathrm{~d}$ HRT for all algae/sludge ratios, ranging from 0 to $100 \%$. Throughout the experiment, each digester maintained a pH within the optimum range (6.6 to 7.6) (McCarty, 1964) without chemical addition. The VFA concentration in each of the digesters was maintained at low levels $(<1000 \mathrm{mg} / \mathrm{L}$ as acetic acid), indicating that methanogenic bacteria were consuming organic acids at nearly the same rate that they were being produced by the acid-forming bacteria.

Greater sludge content in the feed led to proportionally greater methane yield, methane production, and VS destruction. The wastewater sludge was apparently more readily digested by the anaerobic bacteria than algae biomass, confirming earlier studies. 
Co-digestion with wastewater sludge may have provided minimal synergistic benefit to algae methane yield. The synergistic effect on algae methane yield through co-digestion can be seen in the difference between the observed yield for the $80 \%, 60 \% \%, 40 \%$, and $20 \%$ algae digesters and the anticipated yield (Figure 12). The anticipated yield represents the yield if there was no synergistic benefit of co-digestion and was calculated using the observed yield for $100 \%$ algae and $100 \%$ sludge digesters. Potentially the benefit to methane yield through co-digestion could have been greater if a higher $\mathrm{C}: \mathrm{N}$ ratio co-substrate had been used.

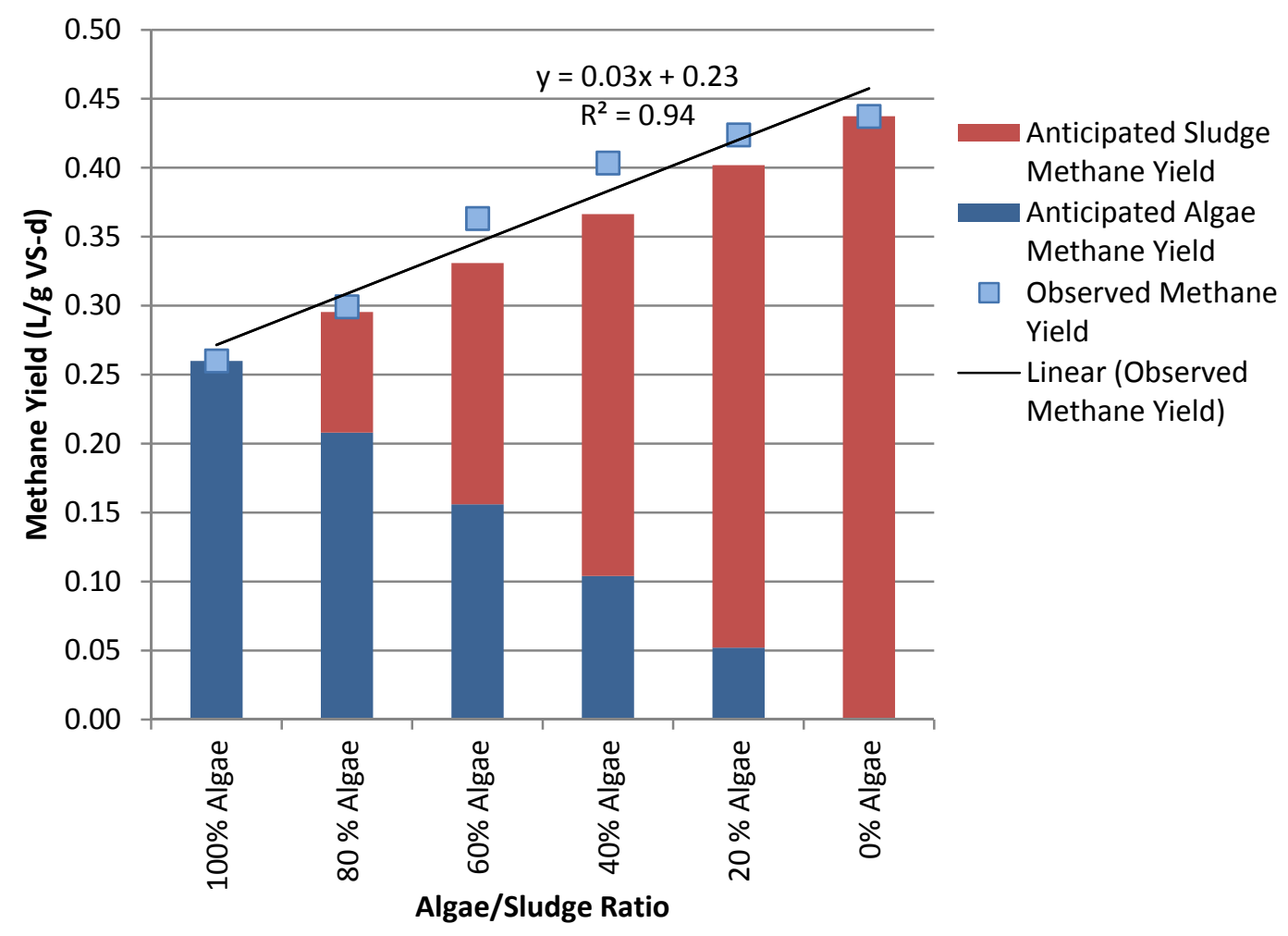

Figure 12. Observed effect of algae/sludge ratio on methane yield compared to the anticipated yield

The linear relationship observed between volatile solids destruction and the algae/sludge ratio also indicates an absence of increased digestion of the algae when co-digested with the wastewater sludge. As with methane yield, volatile solids destruction would not have increased 
linearly with increased sludge concentration if co-digestion of algae and wastewater sludge provided a significant synergistic benefit (Figure 6).

\subsection{Organic Loading Rate (Experiment \#2)}

Ignoring complicating factors, high OLRs are desirable in terms of decreasing the volume of digester vessel needed for a given biomass flow. Experiment \#2 showed increased methane production at higher organic loading rates, with $4 \mathrm{~g} \mathrm{VS} / \mathrm{L}-\mathrm{d}$ being the highest loading in the experiments reported herein. However, to increase OLR without decreasing HRT requires increasing the concentration of the algal slurry. Using typical full-scale thickening technologies, the range for solids concentration achievable is $4-8 \%$ or $40-80 \mathrm{~g} / \mathrm{L}$ (Tchobanoglous et al., 2003). As an example, the Sunnyvale WPCP achieves 5\% solids content in harvested algae float. Thus, the highest OLR that can be achieved from algae with $5 \%$ solids, $85 \% \mathrm{VS}$, and a 20 -day HRT is $2.1 \mathrm{~g} \mathrm{VS} / \mathrm{L}-\mathrm{d}$. At the upper end of the achievable solids concentration, $8 \%$ solids, $85 \% \mathrm{VS}$, and a 20-day HRT equates to an organic loading rate of $3.4 \mathrm{~g} \mathrm{VS} / 1 \mathrm{~d}$. Thus, unusual thickening procedures or the addition of more concentrated co-substrates would be needed to reach an OLR of $4 \mathrm{~g} \mathrm{VS} / \mathrm{L}-\mathrm{d}$ with algae at a wastewater pond treatment facility.

Digester OLR, and consequently methane production, are also limited by the concentration of digester feed that can be mixed within an anaerobic digester. For example, experiments performed on municipal solid waste and sewage sludge found that an operational problem, the development of an unmixed upper layer, was encountered when the digester feed solids concentration approached 10\% (James et al., 1980).

Experiment \#2 showed that stable digestion of $100 \%$ algae could be performed at an OLR of $4 \mathrm{~g} \mathrm{VS} / \mathrm{L}-\mathrm{d}$ and an HRT of 20 days. However, the actual OLR was higher for part of the experiment. During the course of Experiment \#2, the total liquid volume in Digester \#2-1 and \#22 decreased gradually due to leakage of fluid during the feeding and effluent withdrawal process. The conversion of volatile solids into biogas could also have contributed the decreased liquid 
volume to a minor extent. This decreased liquid volume occurred over a period of one month and resulted in a decreased liquid volume within the digesters of approximately $50-100 \mathrm{~mL}$, a $10 \%$ $20 \%$ decrease. The decreased digester liquid volume effectively increased the OLR and had a noticeable effect on the stability of the digesters operating at a nominal $4 \mathrm{~g} \mathrm{VS} / \mathrm{L}-\mathrm{d}$. As the digester volume decreased, the OLR of these digesters increased to approximately 4.5 to $5 \mathrm{~g}$ $\mathrm{VS} / \mathrm{L} \mathrm{d}$. As the OLR exceeded $4 \mathrm{~g}$ VS/L-d, the digesters became unstable, measured by an increase in VFA concentration and a decrease in $\mathrm{pH}$ and biogas production (Figure 13). This decrease in digester liquid volume occurred in all digesters, but the increasing VFA and decreased $\mathrm{pH}$ and biogas production only occurred in the digesters with the high $4 \mathrm{~g} \mathrm{VS} / \mathrm{L}-\mathrm{d}$ OLR.

To remedy the decreased digester volume, the withdrawal rate from the digesters was decreased until the digesters returned to the target volume of $500 \mathrm{ml}$. After the correct digester liquid volume was reached, the VFA concentration decreased and the $\mathrm{pH}$ and biogas production returned to previous levels. This observed sensitivity of digester stability to OLR is an indicator that an OLR of $4 \mathrm{~g} \mathrm{VS} / \mathrm{L}-\mathrm{d}$ is near the maximum that can be maintained for $100 \%$ and $80 \%$ algae digestion with wastewater sludge. 

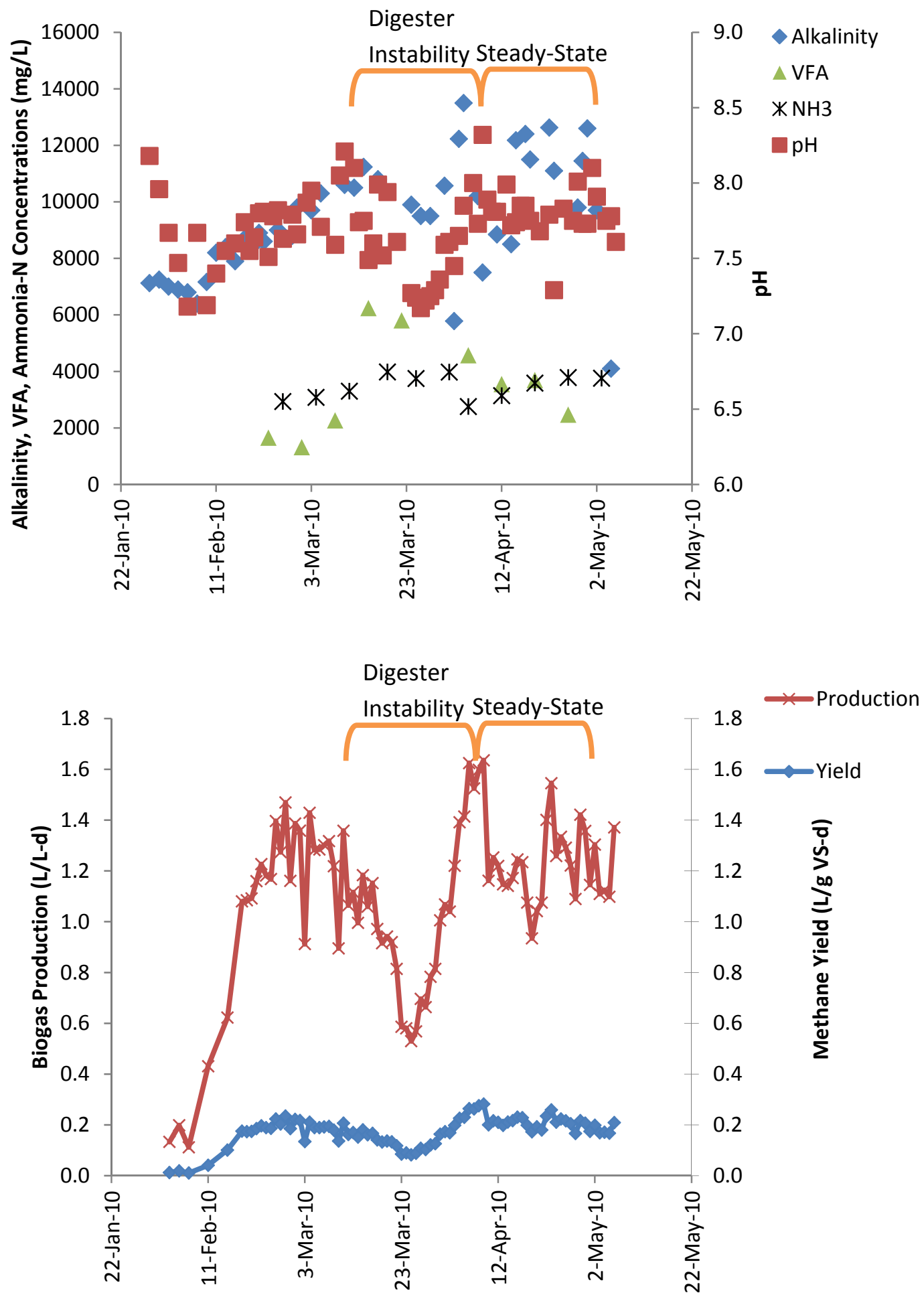

Figure 13. Digester \#2-1 (100\% algae, OLR 4 g VS/L-d, HRT 20 d) exhibiting instability symptoms due to excessive OLR caused by loss of digester volume due to leakage and VS conversion to biogas. 
The volatile solids destruction did not decrease proportionally with OLR, which was not anticipated. For the $100 \%$ algae digesters, volatile solids destruction was nearly equal in the high and low OLR digesters. However, the volatile solids destruction for the $80 \%$ algae digesters was slightly lower at the higher OLRs, as expected (Figure 9).

\subsection{Hydraulic Residence Time (Experiment \#2)}

This experiment showed that increasing the digester volume to double the HRT and halve the OLR did not increase the methane yield in the algae digesters. Digester \#2-3 and \#2-10 were both fed the same substrate ( $80 \%$ algae, $40 \mathrm{~g} \mathrm{VS} / \mathrm{L}$ ) but operated at different HRT (20d versus 40d) and produced equivalent methane yields (Figure 10). These results showed that there was no benefit to algae digestion methane yield with a longer HRT through increased digester volumes, and that the methane production decreased by $53 \%$.

Algae are more resistant to digestion than wastewater sludge and increasing the hydraulic residence time does not significantly increase the breakdown of the recalcitrant components of the algae. This could be because algae cell walls are resistant to hydrolysis, and anaerobic bacteria require a longer HRT to penetrate them through hydrolysis (Sialve et al., 2009). Experiment \#2 indicates that even 40 days does not provide sufficient time for substantially more complete digestion. Based on this study and algae digestion experiments at 10-d HRT, which required regular addition of base to maintain $\mathrm{pH}$ (Yen \& Brune, 2007), the optimal HRT for algae digestion is about 20 days.

\subsection{Algae Digester Dewatering}

The dewatering experiments performed on the digester effluent demonstrated that digested algae biomass could be dewatered to an equivalent or higher solids concentration than conventional wastewater sludge. The effluent from Digester \#2-1 and \#2-2 (100\% Algae, $4 \mathrm{~g}$ VS/L-d OLR) achieved an average solids concentration of 10\% after dewatering at a cationic polymer dosage of $5 \mathrm{~g} / \mathrm{kg}$ TS. At the same dosage, effluent from Digester \#2-3 (80\% Algae OLR 
$2 \mathrm{~g} \mathrm{VS} / \mathrm{L}-\mathrm{d}$ ) dewatered to a solids concentration of $13 \%$. To achieve a solids concentration of $8 \%$, the conventional wastewater sludge from the WRF Digester \#2 effluent required a polymer dosage of $15 \mathrm{~g} / \mathrm{kg} \mathrm{TS}$, triple that of the algae digester effluent.

The highest increase in solids percentage from digester effluent to dewatered solids was observed in Digester \#2-3 (80\% Algae OLR 2 g VS/L-d), an increase of 320\%. The digesters with high OLRs (4 g VS/L-d) exhibited less significant increases in solids concentration from the dewatering process (38\% increase on average), primarily due the high solids content of the digester effluent prior to dewatering. The WRF dewatered solids concentration increased $161 \%$ during the dewatering process but required triple the dosage of polymer.

Dewatering of digester effluent is important because it impacts the sludge disposal costs associated with anaerobic digestion. Typically, wastewater sludge is disposed by dewatering and transporting via truck to a disposal or composting facility. To minimize sludge hauling costs, it is necessary to maximize the solids fraction of the dewatered sludge to avoid transporting excess water retained by the sludge. The results of the dewatering experiment indicated that algae digester effluent would dewater as effectively as conventional wastewater sludge. It should be noted, however, that the feed for the algae digesters was frozen prior to being fed to the digesters, while the WRF digester sludge was not, and freezing sludge can be beneficial to the dewatering process (Tchobanoglous et al., 2003).

\subsection{Algae Digestion Heat Requirement and Energy Balance}

Anaerobic digestion of wastewater sludge requires significant heating and energy input. The digester and the incoming feed typically require heating, and electricity is needed to pump the sludge, mix the digester, and to process the biogas. Since the methane yield from algae digestion is less than that of wastewater sludge digestion, it can be questioned whether algae digestion is worthwhile in terms of net energy output. To answer this question, an energy balance model for 
the anaerobic digestion of algae was developed (Figure 14). The model was applied to two scenarios:

1) Newly-built anaerobic digester operating with $100 \%$ algae feed

2) Conversion of an existing, sludge-fed anaerobic digester to include co-digestion of algae

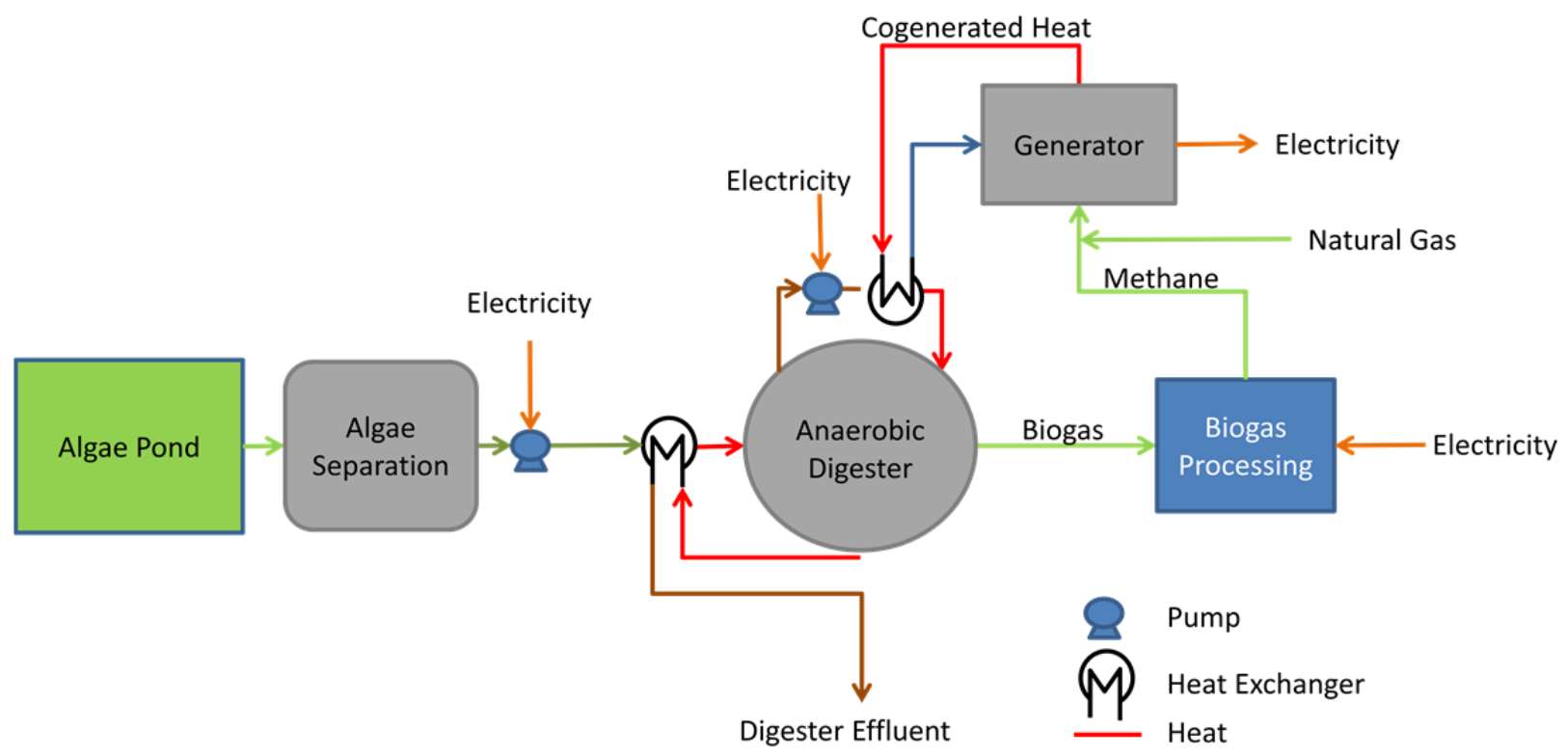

Figure 14. Algae digestion model - heat and energy analysis flow diagram

To develop the model, initial assumptions regarding the operating parameters of the facultative pond wastewater treatment facility were made (Table 4). The needed digester volume is based on a 30-d HRT. The HRT of 30 days was selected in order for the digester tank heat loss estimates to be conservative. The algae fed was assumed to contain 5\% TS and $85 \%$ VS in TS.

Table 4. Facultative pond wastewater treatment facility assumptions

\begin{tabular}{cccccc}
\hline $\begin{array}{c}\text { Pond Flow Rate } \\
\left(\mathrm{m}^{3} / \mathrm{d}\right)\end{array}$ & $\begin{array}{c}\text { Algae Yield } \\
\left(\mathrm{kg} \mathrm{TSS} / \mathrm{m}^{3}\right)\end{array}$ & $\begin{array}{c}\text { \% TS that is } \\
\text { VS }\end{array}$ & $\begin{array}{c}\text { Harvested } \\
\text { Algae TS }(\mathrm{g} \\
\mathrm{TS} / \mathrm{L})\end{array}$ & $\begin{array}{c}\text { Sludge Flow } \\
\text { Rate }\left(\mathrm{m}^{3} / \mathrm{d}\right)\end{array}$ & $\begin{array}{c}\text { Digester Volume } \\
\left(\mathrm{m}^{3}\right)\end{array}$ \\
\hline 135,000 & 0.05 & 85 & 50 & 69 & 4,030 \\
\hline
\end{tabular}

Heat is required initially to heat the incoming digester feed to the mesophilic digester operating temperatures $\left(30\right.$ to $\left.38^{\circ} \mathrm{C}\right)$ and to make up for heat losses from the digester to the 
outside environment. The heating requirements for digesters are dependent on ambient air temperatures, among other factors discussed below. As examples, the heat and energy analysis was performed using the climate conditions for two locations, Sunnyvale, Calif. (Weather.com, 2010) and Logan, Utah (Western Regional Climate Center, 2010), both communities with large treatment pond systems. The California location is a Mediterranean climate, and the Utah location is in a high continental desert. The initial digester feed temperature was assumed to be equal to the mean air temperature for the month (Table 5). The digester operating temperature for this analysis was assumed to be $37.5^{\circ} \mathrm{C}$, the high end of the mesophilic temperature range and the temperature used at Sunnyvale for sludge digestion. The specific heat of the algae was assumed to be $4,200 \mathrm{~J} / \mathrm{kg}_{-}{ }^{\circ} \mathrm{C}$, similar to that of conventional sludge (Tchobanoglous et al., 2003).

Table 5. Mean monthly air temperatures used in heat balance analysis

\begin{tabular}{ccc}
\hline Month & \multicolumn{2}{c}{ Mean Air Temperature $\left({ }^{\circ} \mathrm{C}\right)$} \\
\hline January & Sunnyvale, Calif. & Logan, Utah \\
February & 10 & -4 \\
March & 12 & -2 \\
April & 14 & 3 \\
May & 16 & 8 \\
June & 18 & 13 \\
July & 21 & 18 \\
August & 22 & 23 \\
September & 22 & 22 \\
October & 21 & 17 \\
November & 18 & 10 \\
December & 13 & 3 \\
\hline
\end{tabular}

The second component of the heating requirement for anaerobic digestion is the heat lost from the digester to the outside environment. This component is dependent upon the digester design and construction materials, the ambient air temperature, depth of the digester tank that is below the ground surface, and the local groundwater level. For the heat and energy balance calculations, the following assumptions were made for the local conditions and construction methods. 
- Air temperature was equal to the average air temperature for the month

- Digester tank is cylindrical

- Two-thirds of the digester tank height is below the ground surface

- Groundwater level is at the same elevation as the floor of the digester

- Typical digester construction methods and associated heat transfer coefficients (Table 6)

Table 6. Typical digester construction methods and heat transfer coefficients (Tchobanoglous et al., 2003)

\begin{tabular}{ccccc}
\hline Component & Material & $\begin{array}{c}\text { Thickness } \\
(\mathrm{m})\end{array}$ & Notes & $\begin{array}{c}\text { Heat Transfer } \\
\text { Coefficient } \\
\left(\mathrm{W} / \mathrm{m}^{2}{ }^{\circ} \mathrm{C}\right)\end{array}$ \\
\hline Above Ground Walls & Concrete & 0.3 & Insulated & 0.7 \\
Below Ground Walls & Concrete & 1.3 & Insulated / Dry Earth & 0.625 \\
Floors & Concrete & 0.3 & Moist Earth & 2.85 \\
Fixed Cover & Concrete & 0.1 & Insulated & 1.4 \\
\hline
\end{tabular}

A cogeneration process is assumed, with a typical thermal recovery efficiency of $50 \%$ from the engine water jacket and exhaust gas (UNEP, 2006). The thermal energy recovered from the electricity generation must then pass through a heat exchanger to be transferred to the digester sludge. The model used a typical heat exchanger transfer efficiency of $80 \%$ (Liu \& Lipták, 1999).

To assist in the digester heating, additional thermal energy can be recovered via a heat exchanger on the digester effluent and influent. This heat exchanger was assumed to operate at $80 \%$ efficiency. Heat produced from the exothermic digester reactions was not included in the model.

To provide a net energy benefit, the electricity produced from co-generation must exceed the electrical energy requirements required to pump the algae float, mix the digester, and to process the biogas. (Algae harvesting from the pond effluent is assumed to be required by regulation and thus is not considered a parasitic loss.) The typical electrical recovery efficiency from a small- 
scale co-generation facility is $30 \%$ (Walla $\&$ Schneeberger, 2008). The value of the electricity produced was assumed to be $0.06 \$ / \mathrm{kW}-\mathrm{hr}$. Typical mixing energy requirements for anaerobic digestion are $0.005-0.008 \mathrm{~kW} / \mathrm{m}^{3}$ (Tchobanoglous et al., 2003). The model assumed continuous mixing at $0.008 \mathrm{~kW} / \mathrm{m}^{3}$.

Prior to being converted to electrical energy, the biogas must be processed to remove hydrogen sulfides, $\mathrm{CO}_{2}$, water, and other contaminants. This processing requires electrical inputs of about $0.301 \mathrm{~kW}-\mathrm{hrs} / \mathrm{m}^{3}$ of biogas (Collet et al., 2010).

\subsubsection{Scenario 1: Heating Requirement for a Digester Fed 100\% Algae}

For Scenario 1, a digester fed with 100\% algae, the results of the heat balance calculation show that there is sufficient heat recovered from the cogeneration process to maintain the anaerobic digestion of facultative wastewater pond algae in both climates (Table 7).

Table 7. Operating conditions assumed for a digester fed $100 \%$ algae harvested from facultative ponds treating $134,000 \mathrm{~m}^{3} / \mathrm{d}$

\begin{tabular}{cccccc}
\hline $\begin{array}{c}\text { Digester } \\
\text { Feed }\end{array}$ & $\begin{array}{c}\text { Digester } \\
\text { HRT }(\mathrm{d})\end{array}$ & $\begin{array}{c}\text { OLR } \\
(\mathrm{g} \text { VS/L-d) }\end{array}$ & $\begin{array}{c}\text { Methane Produced } \\
(\mathrm{L} / \mathrm{d})\end{array}$ & $\begin{array}{c}\text { Maximum Heating } \\
\text { Recovered Heat } \\
\text { to Maintain } \\
\text { Temperature } \\
(\mathrm{MJ} / \mathrm{d})\end{array}$ \\
\hline $100 \%$ Algae & 30 & 1.41 & $1,481,000$ & 32,000 & 30,000 \\
\hline
\end{tabular}

The digester in the model was assumed to be sized for winter algae production, and thus there would be a consistent flow rate of algae to the digester, with excess algae produced during the summer months requiring disposal. The heat available for digester heating does not vary with seasonal temperatures as the heat recovered through co-generation and through the digester's effluent/influent heat exchanger exceeds the heating requirements of the digester at all temperatures (Figure 15). 


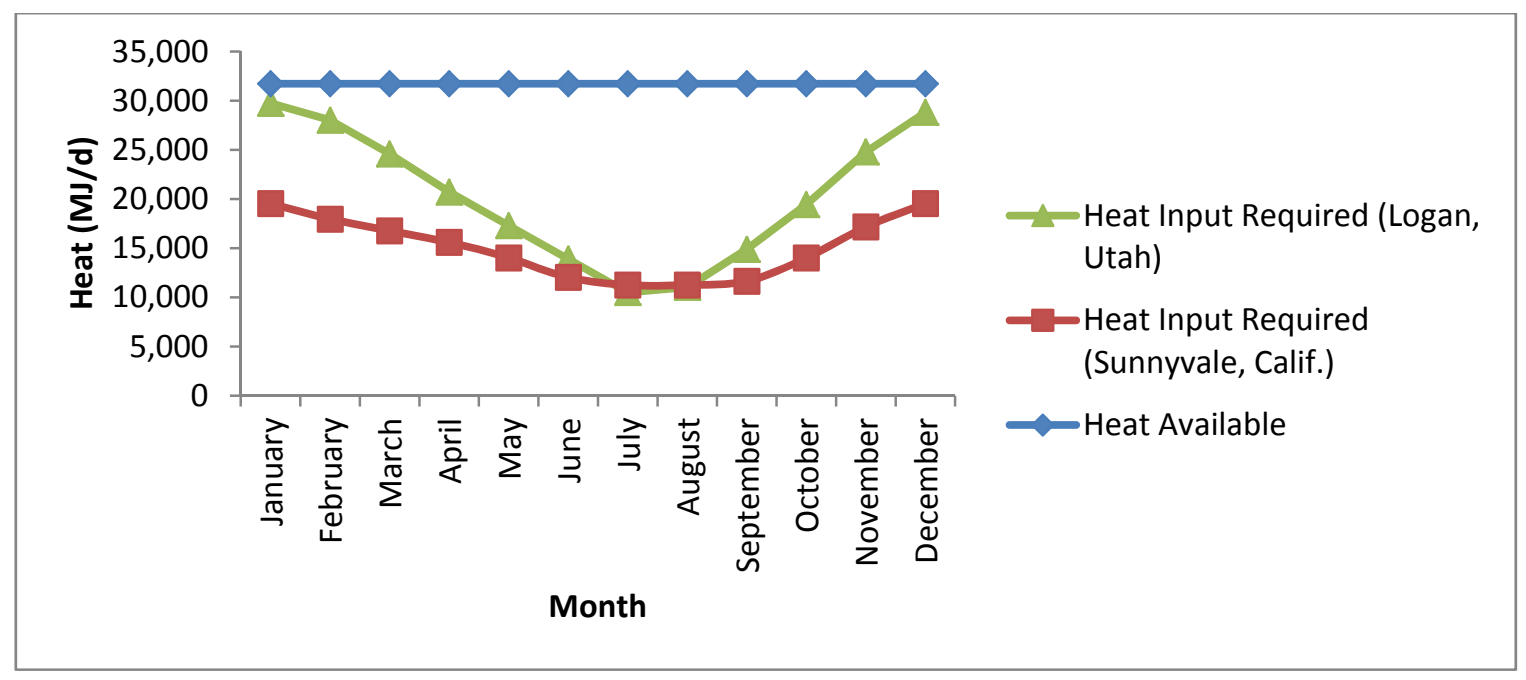

Figure 15. Heat required and head available for a digester fed $100 \%$ algae in two different climates (Sunnyvale, Calif. and Logan, Utah)

\subsubsection{Scenario 2 Existing Facility Conversion from Sludge to Sludge+Algae Co-Digestion}

Scenario 2 considered a facultative wastewater pond facility with existing anaerobic digesters that begins algae digestion. The addition of the algae float to the digester feed significantly decreases the HRT and increases the OLR. The model was initially run with a digester operating in sludge-only mode, without algae digestion. The model was then modified to include the addition of the algae to the digester feed, which significantly impacts the operating parameters and the energy production of the facultative pond wastewater facility anaerobic digester (Table 8).

Table 8. Operating conditions and electricity production for conversion of a sludge digester to algae co-digestion

\begin{tabular}{cccccc}
\hline & & & Value of \\
Digester Feed & Digester HRT (d) & $\begin{array}{c}\text { OLR } \\
(\mathrm{g} \text { VS/L-d) }\end{array}$ & $\begin{array}{c}\text { Methane } \\
\text { Produced (L/d) }\end{array}$ & $\begin{array}{c}\text { Electricity } \\
\text { Produced } \\
(\mathrm{kW}-\mathrm{hr} / \mathrm{d})\end{array}$ & $\begin{array}{c}\text { Electricity } \\
\text { Produced } \\
(\$ / \mathrm{d})\end{array}$ \\
\hline Sludge Only & 58 & 0.7 & $1,290,000$ & 3,000 & 185 \\
Sludge \& Algae & 20 & 2.1 & $2,770,000$ & 6,700 & 410 \\
\hline
\end{tabular}

The addition of algae feed to the digester increased electricity generation by $120 \%$, or the equivalent of $\$ 225$ per day at $0.06 \$ / \mathrm{kWh}$. The HRT is the limiting factor that determines the 
maximum amount of algae that can be added to the digester. Due to thickening technology limitations, the minimum HRT is exceeded prior to reaching the maximum OLR.

The conversion to algae digestion would decrease the organic loading on the facultative ponds as the algae would be disposed of offsite instead of being returned to the pond. The conversion to algae co-digestion would increase the intervals between pond dredging, but would lead to increased trucking and disposal costs from the increased sludge production. Another option would be to discharge digested algae into the facultative pond. This route would not decrease dredging as significantly, but it would decrease the organic loading on the pond compared to the current method of operation and would not increase short-term trucking costs.

\section{Conclusions}

Through anaerobic digestion, algae produced at facultative pond wastewater treatment plants can be used as a renewable energy source. Co-digestion of algae and wastewater sludge is stable at all algae/sludge ratios with an OLR of $2 \mathrm{~g} \mathrm{VS/L-d} \mathrm{and} \mathrm{a} \mathrm{20-day} \mathrm{HRT.} \mathrm{However,} \mathrm{little} \mathrm{or} \mathrm{no}$ synergistic benefit to algae methane yield from the co-digestion with wastewater sludge at this OLR was observed.

Stable anaerobic digestion of $100 \%$ algae can be achieved at OLRs up to $4 \mathrm{~g} \mathrm{VS} / \mathrm{L}-\mathrm{d}$ at an HRT of 20 days, but OLR higher than $4 \mathrm{~g} \mathrm{VS} / \mathrm{L}-\mathrm{d}$ may lead to unstable and difficult to control digestion. Methane volumetric production as high as $0.90 \mathrm{~L} / \mathrm{L}-\mathrm{d}$ can be achieved with $100 \%$ algae a 20 day HRT and an OLR of $4 \mathrm{~g}$ VS/L-d. However, typical full-scale sludge thickening and digester mixing technologies may limit the solids concentration that can be achieved to less than $4 \mathrm{~g} \mathrm{VS/L-d.} \mathrm{Longer} \mathrm{HRT} \mathrm{(40} \mathrm{days)} \mathrm{through} \mathrm{larger} \mathrm{digester} \mathrm{volumes} \mathrm{did} \mathrm{not} \mathrm{increase}$ methane yield, as the algae contain a higher percentage of recalcitrant solids that were not degraded at a longer HRT, and it significantly decreased methane production. 
Digested algae effluent dewatered as effectively as wastewater sludge digester effluent in this experiment, and thus hauling and disposal rates should be equivalent to conventional dewatered wastewater sludge. However, it is anticipated that even with effective dewatering, the sludge disposal cost will increase with algae co-digestion due to the increased volume of sludge requiring disposal. These costs could be offset by the decreased frequency of dredging required within the facultative ponds.

The heat and energy modeling showed that algae digestion should not require external heat inputs to maintain mesophilic digestion temperatures. Through co-generation, the predicted excess heat produced from the electricity generating process is sufficient to fulfill all digester and sludge heating requirements in moderate climates. An existing wastewater treatment pond facility with sufficient digester capacity could convert to algae digestion with minimal capital cost and significantly increase the electricity generated from its biogas generators. A $120 \%$ increase in electricity generation was estimated for an example facility. Anaerobic digestion of wastewater treatment algae presents an opportunity to develop a renewable energy resource with minimal capital expenditure at facilities with existing digester capacity. 


\section{References}

APHA (2005). Standard Methods for the Examination of Water \& Wastewater. American Public Health Association, Water Environment Federation, and the American Waterworks Association.

Chen, P. H., \& Oswald, W. J. (1998). Thermochemical treatment for algal fermentation. Environment International, 24(8), 889-897. doi:10.1016/S0160-4120(98)00080-4

Collet, P., Hélias, A., Lardon, L., Ras, M., Goy, R., \& Steyer, J. (2010). Life-cycle assessment of microalgae culture coupled to biogas production. Bioresource Technology, In Press, Accepted Manuscript. doi:10.1016/j.biortech.2010.06.154

De Sa, J. (2009). Personnel communication. Operations Manager, Sunnyvale Water Pollution Control Plant, Sunnyvale, Calif.

Downing, J., Bracco, E., Green, F., Ku, A., Lundquist, T., Zubieta, I., \& Oswald, W. (2002). Low cost reclamation using the Advanced Intergrated Wastewater Pond Systems Technology and reverse osmosis. Water Science \& Technology, 45(1), 117-125.

EAO, Inc., \& Bracewell Engineering, Inc. (1988). Alage Digestion Study: City of Sunnyvale, Sunnyvale, Calif.

EPA (2007). Chapter 5 Technology-Based Effluent Limits. NPDES Permit Writer's Manual. U.S. Environmental Protection Agency. Retrieved from http://www.epa.gov/npdes/pubs/chapt 05.pdf

Golueke, C. G., Oswald, W. J., \& Gotaas, H. B. (1957). Anaerobic digestion of algae. Applied and Environmental Microbiology, 5(1), 47.

James, S. C. P. A., Wiles, C. C., Swartzbaugh, J. T., \& Smith, R. B. (1980). Mixing in large-scale municipal solid waste-sewage sludge anaerobic digesters (Vol. 10, pp. 259-272). Presented at the Symposium on Biotechnology in Energy Production and Conservation, Gatlinburg, TN.

Liu, D. H., \& Lipták, B. G. (1999). Environmental engineer's handbook. CRC.

McCarty, P. L. (1964). Anaerobic Waste Treatment Fundamentals. Public Works, 123-126. 
Middlebrooks, E. J., Middlebrooks, C. H., \& Reed, S. C. (1981). Energy Requirement for Small Wastewater Treatment Systems. Journal of the Water Pollution Control Federation, 53(7), 1172-1197.

Western Regional Climate Center (2010). . Retrieved December 18, 2010, from http://www.wrcc.dri.edu/cgi-bin/cliMONtavt.pl?utloga

Weather.com (2010). . Retrieved December 18, 2010, from http://www.weather.com/weather/wxclimatology/monthly/94089

Oswald, W. J., \& Golueke, C. G. (1960). Biological transformation of solar energy. Adv. Appl. Microbiol, 11, 223-242.

Sawyer, C., McCarty, P., \& Parkin, G. (2002). Chemistry for Environmental Engineering and Science (5th ed.). McGraw-Hill Science/Engineering/Math.

Sialve, B., Bernet, N., \& Bernard, O. (2009). Anaerobic digestion of microalgae as a necessary step to make microalgal biodiesel sustainable. Biotechnology Advances, 27(4), 409-416.

Tchobanoglous, G., Theisen, H., \& Vigil, S. (1993). Integrated Solid-Waste Management: Engineering Principles and Management Issues. London: McGraw-Hill.

Tchobanoglous, G., Burton, F. L., \& Stensel, H. D. (2003). Wastewater Engineering: Treatment and Reuse. New York: McGraw-Hill Science/Engineering/Math.

Tchobanoglous, G., Burton, F. L., \& Stensel, H. D. (2003). Wastewater engineering: treatment and reuse. New York: McGraw-Hill Science/Engineering/Math.

UNEP. (2006). Thermal Energy Equipment: Cogeneration. Energy Efficiency Guide for Industry in Asia (pp. 7-8). United Nations Environment Program. Retrieved from www.retscreen.net/fichier.php/1000/Chapter-Cogeneration.pdf

Walla, C., \& Schneeberger, W. (2008). The optimal size for biogas plants. Biomass and Bioenergy, 32(6), 551-557.

Yen, H. W., \& Brune, D. E. (2007). Anaerobic co-digestion of algal sludge and waste paper to produce methane. Bioresource Technology, 98(1), 130-134. 